\title{
Molecular interactions of miR-338 during tumor progression and metastasis
}

\author{
Meysam Moghbeli* (1)
}

\author{
${ }^{*}$ Correspondence: \\ Meysam_moghbeli@yahoo.com; \\ moghbelim@mums.ac.ir \\ Department of Medical \\ Genetics and Molecular \\ Medicine, School of Medicine, \\ Mashhad University of Medical \\ Sciences, Mashhad, Iran
}

\begin{abstract}
Background: Cancer, as one of the main causes of human deaths, is currently a significant global health challenge. Since the majority of cancer-related deaths are associated with late diagnosis, it is necessary to develop minimally invasive early detection markers to manage and reduce mortality rates. MicroRNAs (miRNAs), as highly conserved non-coding RNAs, target the specific mRNAs which are involved in regulation of various fundamental cellular processes such as cell proliferation, death, and signaling pathways. MiRNAs can also be regulated by long non-coding RNAs (IncRNAs) and circular RNAs (circRNAs). They are highly stable in body fluids and have tumor-specific expression profiles, which suggest their suitability as efficient non-invasive diagnostic and prognostic tumor markers. Aberrant expression of miR-338 has been widely reported in different cancers. It regulates cell proliferation, migration, angiogenesis, and apoptosis in tumor cells.
\end{abstract}

Main body: In the present review, we have summarized all miR-338 interactions with other non-coding RNAs (ncRNAs) and associated signaling pathways to clarify the role of miR-338 during tumor progression.

Conclusions: It was concluded that miR-338 mainly functions as a tumor suppressor in different cancers. There were also significant associations between miR-338 and other ncRNAs in tumor cells. Moreover, miR-338 has a pivotal role during tumor progression using the regulation of WNT, MAPK, and PI3K/AKT signaling pathways. This review highlights miR-338 as a pivotal ncRNA in biology of tumor cells.

Keywords: Non-coding RNA, MicroRNA, MiR-338, Cancer, Biomarker

\section{Background}

Cancer is the leading cause of deaths and remains a significant challenge for human health globally. Improving the quality of life and prolonging patient survival are the main aims of cancer therapy. However, low efficiency of conventional treatments highlights the importance of effective tumor-specific therapeutic strategies [1]. Non-coding RNAs (ncRNAs) are important post-transcriptional regulators that affect cell apoptosis, proliferation, and differentiation [2-4]. MiRNAs are a group of short ncRNAs (19-24 nucleotides) that target mRNAs using binding with the $3^{\prime}$-untranslated region (UTR), resulting in mRNA degradation and translational suppression [5]. They are categorized based on author(s) and the source, provide a link to the Creative Commons licence, and indicate if changes were made. The images or other third party material in this article are included in the article's Creative Commons licence, unless indicated otherwise in a credit line to the material. If material is not included in the article's Creative Commons licence and your intended use is not permitted by statutory regulation or exceeds the permitted use, you will need to obtain permission directly from the copyright holder. To view a copy of this licence, visit http:// creativecommons.org/licenses/by/4.0/. 
their genomic origin into intergenic, intronic, and exonic. Aberrant expression of miRNAs has been reported during tumor progression $[6,7]$. Based on the targeted mRNA, miRNAs can function as tumor suppressors or oncogenes [8,9]. Clarification of miRNA mechanisms during pathogenesis of human disorders paves the way for introducing novel miRNA-based therapeutic modalities or diagnostic markers. MiRNAs are tissue specific and resistant to plasma RNases, which suggests their use as unique non-invasive diagnostic tumor markers [10]. Since the majority of tumors are detected in advanced stages with a poor prognosis, non-invasive and sensitive markers are required for early stage tumor detection. Circulating miRNAs are highly stable in body fluids and have tumor-specific expression profiles, suggesting their suitability as efficient noninvasive diagnostic and prognostic tumor markers [11, 12]. MiR-338 is located within an intron of the AATK gene that has an essential role during neuron development [13]. In the present review, we have summarized all of the reported miR-338 targets and associated signaling pathways and other non-coding RNAs to clarify the molecular mechanisms of miR-338 during tumor progression in different cancers (Table 1).

\section{Circular RNAs}

CircRNAs are generated by back-splicing characterized by a closed loop [14]. They are involved in transcriptional regulation by microRNA sponging, which is critical in tumor cell proliferation, apoptosis, angiogenesis, and metastasis [15, 16]. Lung cancer is the second most frequent and leading cause of cancer-related deaths in the world [17, 18]. The majority of lung tumors are non-small cell lung cancer (NSCLC) cases [19]. Circ_0001649 is a circRNA transcribed from SHPRH. It was reported that there was circ_0001649 down regulation in NSCLC tissues and cell lines, which was correlated with advanced TNM stage and lymph node involvement. It inhibited cell proliferation and migration of NSCLC cells through miR-338-5p sponging [20]. Renal cell carcinoma (RCC) accounts more than $90 \%$ of renal cancers [21]. Clear cell RCC (ccRCC) is the most frequent histological type of RCC [22]. Caveolin-1 (CAV1) is a scaffold protein that interacts with G-protein and is involved in regulation of WNT and TGF $\beta$ signaling pathways [23]. It was reported that there was circAKT1 upregulation in ccRCC tissues in comparison with normal margins, which was associated with poor prognosis, TNM stage, and lymph node involvement. CircAKT1 induced cell proliferation, migration, and epithelial-mesenchymal transition (EMT) via miR-338-3p inhibition, which resulted in CAV1 upregulation [24]. Bromodomain containing 4 (BRD4) is a chromatin reader protein and transcriptional regulator that binds acetylated histones during cell proliferation [25-27]. It was reported that there was circ-0007841 up-regulation in multiple myeloma (MM). It also induced cell proliferation and metastasis while suppressing apoptosis in MM cells via miR-338-3p decoy to up-regulate BRD4 [28]. TYRO3 is a tyrosine kinase significantly upregulated in various tumors, and induces cancer cell proliferation, EMT, and drug resistance [29-31]. There was an increased level of circRAE1 in CRC tissues that was correlated with advanced TNM stage, tumor size, and lymph node involvement. It also promoted colorectal tumor cell migration by miR388-3p sponging to upregulate TYRO3 [32]. RAB14 is an oncogenic GTPase involved in cell proliferation and invasion through regulation of the AKT pathway [33, 34]. There was significant circ-0000326 upregulation in lung cancer tissues compared with normal 
Table 1 molecular targets of miR-338 during tumor progressions

\begin{tabular}{|c|c|c|c|c|c|c|}
\hline Study & Year & Type & Gene & Target & Samples & Function \\
\hline Liu [20] & 2018 & Lung & Circ-0001649 & $\operatorname{miR}-338-5 p$ & $\begin{array}{l}53 \mathrm{NT}^{*} \text { A549, } \\
\text { H358, H1299, } \\
\text { and H1581 cell } \\
\text { lines }\end{array}$ & $\begin{array}{l}\text { Inhibited cell } \\
\text { proliferation and } \\
\text { migration }\end{array}$ \\
\hline Zhu [24] & 2020 & Renal & Circ-AKT1 & miR-338-3p & $\begin{array}{l}70 \text { NT 768-O, } \\
\text { A498, ACHN, } \\
\text { Caki-1, and } \\
\text { OS-RC-2 cell } \\
\text { lines }\end{array}$ & $\begin{array}{l}\text { Induced cell } \\
\text { proliferation, } \\
\text { migration, and } \\
\text { EMT }\end{array}$ \\
\hline Wang [28] & 2020 & Myeloma & Circ-0007841 & miR-338-3p & $\begin{array}{l}41 \text { patients and } \\
41 \text { healthy } \\
\text { controls } \\
\text { (plasma) H929 } \\
\text { and OPM2 cell } \\
\text { lines }\end{array}$ & $\begin{array}{l}\text { Induced cell prolif- } \\
\text { eration }\end{array}$ \\
\hline Du [32] & 2020 & Colorectal & Circ-RAE1 & miR-338-3p & $\begin{array}{l}80 \text { NT HCT116, } \\
\text { SW620, HT29, } \\
\text { and SW480 cell } \\
\text { lines }\end{array}$ & $\begin{array}{l}\text { Induced cell } \\
\text { migration }\end{array}$ \\
\hline $\mathrm{Xu}[35]$ & 2020 & Lung & Circ-0000326 & miR-338-3p & $\begin{array}{l}100 \text { NT A549, } \\
\text { SPC-A1, H1299, } \\
\text { and H1975 cell } \\
\text { lines }\end{array}$ & $\begin{array}{l}\text { Induced tumor } \\
\text { progression }\end{array}$ \\
\hline Shu [38] & 2020 & Thyroid & Circ-HIPK3 & $\operatorname{miR}-338-3 p$ & $\begin{array}{l}10 \text { NT K1, CAL-62, } \\
\text { and TPC-1 cell } \\
\text { lines }\end{array}$ & $\begin{array}{l}\text { Induced progres- } \\
\text { sion and invasion }\end{array}$ \\
\hline Liu [39] & 2020 & Liver & Circ-104566 & miR-338-3p & $\begin{array}{l}87 \text { NT SK-HEP-1, } \\
\text { HLE, SNU449, } \\
\text { Hep-3B, and } \\
\text { Huh7 cell lines }\end{array}$ & $\begin{array}{l}\text { Induced tumor } \\
\text { progression }\end{array}$ \\
\hline Xiong [41] & 2019 & Glioma & Circ-SMO742 & miR-338-3p & $\begin{array}{l}10 \text { NT A172 and } \\
\text { U-87MG cell } \\
\text { lines }\end{array}$ & $\begin{array}{l}\text { Induced cell prolif- } \\
\text { eration }\end{array}$ \\
\hline $\mathrm{Pu}[43]$ & 2020 & Liver & Circ-0000092 & miR-338-3p & $\begin{array}{l}40 \text { NT Hep3B, } \\
\text { LM3, MHCC97L, } \\
\text { Sk-hep1, and } \\
\text { HepG2 cell } \\
\text { lines }\end{array}$ & $\begin{array}{l}\text { Induced tumor } \\
\text { progression }\end{array}$ \\
\hline Qian [47] & 2020 & Cervical & Circ-HIPK3 & $\operatorname{miR}-338-3 p$ & $\begin{array}{l}45 \text { NT HeLa, } \\
\text { CaSki, SiHa, } \\
\text { C-33A, C-4I, } \\
\text { and SW756 cell } \\
\text { lines }\end{array}$ & Induced EMT \\
\hline $\operatorname{Jin}[48]$ & 2020 & Gastric & Circ-HIPK3 & miR-338-3p & $\begin{array}{l}31 \text { NT MGC803 } \\
\text { and BGC823 } \\
\text { cell lines }\end{array}$ & $\begin{array}{l}\text { Induced cell } \\
\text { migration }\end{array}$ \\
\hline Xiang [49] & 2020 & Osteosarcoma & Circ-CCDC66 & miR-338-3p & $\begin{array}{l}12 \text { NT SW1353 } \\
\text { and U2OS cell } \\
\text { lines }\end{array}$ & $\begin{array}{l}\text { Induced tumor } \\
\text { invasion }\end{array}$ \\
\hline Yang [50] & 2020 & Colorectal & Circ-0137008 & miR-338-5p & $\begin{array}{l}30 \text { NT HT29, } \\
\text { HCT116, HCT8, } \\
\text { LOVO, SW480, } \\
\text { and SW620 cell } \\
\text { lines }\end{array}$ & $\begin{array}{l}\text { Inhibited cell } \\
\text { proliferation and } \\
\text { migration }\end{array}$ \\
\hline Yan [56] & 2017 & Esophageal & SNHG1 & miR-338-3p & $\begin{array}{l}56 \text { NT } 6 \text { primary } \\
\text { cell culture }\end{array}$ & $\begin{array}{l}\text { Induced cell prolif- } \\
\text { eration }\end{array}$ \\
\hline Zhang [60] & 2019 & Neuroblastoma & SNHG1 & miR-338-3p & $\begin{array}{l}33 \text { NT SK-N-SH } \\
\text { and SK-N-AS } \\
\text { cell lines }\end{array}$ & $\begin{array}{l}\text { Induced cell } \\
\text { proliferation and } \\
\text { migration }\end{array}$ \\
\hline
\end{tabular}


Table 1 (continued)

\begin{tabular}{|c|c|c|c|c|c|c|}
\hline Study & Year & Type & Gene & Target & Samples & Function \\
\hline Li [65] & 2019 & Colorectal & SNHG15 & miR-338-3p & $\begin{array}{l}203 \text { NT HCT116, } \\
\text { SW620, LOVO, } \\
\text { SW480, and } \\
293 \text { T cell lines }\end{array}$ & $\begin{array}{l}\text { Induced cell prolif- } \\
\text { eration }\end{array}$ \\
\hline Zhang [66] & 2019 & Prostate & SNHG15 & miR-338-3p & $\begin{array}{l}\text { LNCAP, DU145, } \\
\text { and PC3 cell } \\
\text { lines }\end{array}$ & $\begin{array}{l}\text { Induced cell prolif- } \\
\text { eration and EMT }\end{array}$ \\
\hline Liu [69] & 2018 & Ovarian & LINC00460 & miR-338-3p & $\begin{array}{l}98 \text { NT SKOV3, } \\
\text { A2780, OVCAR, } \\
\text { and HO-8910 }\end{array}$ & $\begin{array}{l}\text { Increased cell } \\
\text { proliferation and } \\
\text { EMT }\end{array}$ \\
\hline $\mathrm{Hu}[70]$ & 2020 & Prostate & LINC00173 & miR-338-3p & $\begin{array}{l}124 \text { NT DU145, } \\
\text { PC3, and } \\
\text { LNCAP cell } \\
\text { lines }\end{array}$ & $\begin{array}{l}\text { Induced tumor cel } \\
\text { progression }\end{array}$ \\
\hline Wan [71] & 2020 & Glioma & LINC00525 & miR-338-3p & $\begin{array}{l}\text { U87, MO59K, } \\
\text { U118, Hs683, } \\
\text { and LN-18 cell } \\
\text { lines }\end{array}$ & $\begin{array}{l}\text { Regulated migra- } \\
\text { tion and EMT }\end{array}$ \\
\hline Lu [72] & 2020 & Gastric & LINC-00689 & miR-338-3p & $\begin{array}{l}40 \text { NT HGC-27, } \\
\text { SGC-7901, } \\
\text { MGC-803, and } \\
\text { AGS }\end{array}$ & $\begin{array}{l}\text { Induced cell } \\
\text { growth and EMT }\end{array}$ \\
\hline Feng [74] & 2020 & Leukemia & NEAT1 & miR-338-3p & $\begin{array}{l}32 \text { patients } \\
32 \text { healthy } \\
\text { controls KG-1, } \\
\text { HL-60, THP-1, } \\
\text { and U937 cell } \\
\text { lines }\end{array}$ & $\begin{array}{l}\text { Inhibited cell } \\
\text { growth and } \\
\text { migration }\end{array}$ \\
\hline Jing [76] & 2019 & Lung & CRNDE & miR-338-3p & $\begin{array}{l}84 \text { NT A549, } \\
\text { H1299, SPCA1, } \\
\text { and H358 cell } \\
\text { lines }\end{array}$ & $\begin{array}{l}\text { Induced tumor } \\
\text { progression }\end{array}$ \\
\hline Song [79] & 2020 & Esophageal & BANCR & miR-338-3p & $\begin{array}{l}40 \text { NT KYSE450 } \\
\text { and KYSE510 } \\
\text { cell lines }\end{array}$ & $\begin{array}{l}\text { Inhibited tumor } \\
\text { progression }\end{array}$ \\
\hline Luan [80] & 2018 & Cervical & XLOC-006390 & miR-338-3p & $\begin{array}{l}20 \text { NT SiHa, HeLa, } \\
\text { CaSki, C-41, } \\
\text { and C-33A cell } \\
\text { lines }\end{array}$ & $\begin{array}{l}\text { Induced tumor } \\
\text { progression }\end{array}$ \\
\hline Chen [82] & 2020 & Lung & SBF2-AS1 & miR-338-3p & $\begin{array}{l}56 \text { NT A549, } \\
\text { H1650, and } \\
\text { H1975 cell lines }\end{array}$ & $\begin{array}{l}\text { Induced tumor } \\
\text { growth }\end{array}$ \\
\hline Ji [83] & 2019 & Liver & DSCAM-AS1 & miR-338-3p & $\begin{array}{l}48 \text { NT HepG2, } \\
\text { Hep3B, } \\
\text { Huh7, and } \\
\text { SMMC7721 cell } \\
\text { lines }\end{array}$ & $\begin{array}{l}\text { Induced tumor } \\
\text { progression }\end{array}$ \\
\hline Li [85] & 2019 & Oral & OIP5-AS1 & miR-338-3p & $\begin{array}{l}38 \text { NT SCC9, } \\
\text { SCC15, Ca9-22, } \\
\text { and HSU3 cell } \\
\text { lines }\end{array}$ & $\begin{array}{l}\text { Increased cell pro- } \\
\text { liferation, migra- } \\
\text { tion, colony } \\
\text { formation, and } \\
\text { in vivo growth }\end{array}$ \\
\hline $\mathrm{Ma}[89]$ & 2018 & Glioma & miR-338-5p & FOXD1 & $\begin{array}{l}130 \text { NT U251 cell } \\
\text { line }\end{array}$ & $\begin{array}{l}\text { Inhibited cell } \\
\text { proliferation }\end{array}$ \\
\hline Hua [90] & 2017 & Cervical & miR-338-3p & MACC1 & $\begin{array}{l}67 \text { NT HeLa and } \\
\text { CaSki cell lines }\end{array}$ & $\begin{array}{l}\text { Inhibited cell } \\
\text { proliferation }\end{array}$ \\
\hline Jia [91] & 2019 & Osteosarcoma & miR-338-3p & RUNX2, CDK4 & $\begin{array}{l}\text { MG-63 and U2OS } \\
\text { cell lines }\end{array}$ & $\begin{array}{l}\text { Inhibited cell } \\
\text { proliferation and } \\
\text { migration }\end{array}$ \\
\hline
\end{tabular}


Table 1 (continued)

\begin{tabular}{|c|c|c|c|c|c|c|}
\hline Study & Year & Type & Gene & Target & Samples & Function \\
\hline Peng [96] & 2014 & Gastric & miR-338-3p & NRP1 & $\begin{array}{l}41 \text { NT SGC-7901, } \\
\text { HGC-27, AGS, } \\
\text { MKN-45, and } \\
\text { N87 cell lines }\end{array}$ & $\begin{array}{l}\text { Inhibited cell } \\
\text { proliferation and } \\
\text { migration }\end{array}$ \\
\hline Ding [98] & 2019 & Lung & miR-338-3p & NRP1 & $\begin{array}{l}55 \text { NT A549, } \\
\text { HCC827, and } \\
\text { H226 cell lines }\end{array}$ & $\begin{array}{c}\text { Inhibited colony } \\
\text { formation and } \\
\text { cell migration }\end{array}$ \\
\hline Liu [99] & 2015 & Oral & miR-338-3p & NRP1 & $\begin{array}{l}24 \text { NT TCa-8113 } \\
\text { and SCC-15 cell } \\
\text { lines }\end{array}$ & $\begin{array}{l}\text { Inhibited cell } \\
\text { proliferation and } \\
\text { invasion }\end{array}$ \\
\hline Song [112] & 2018 & Gastric & miR-338-3p & EPHA2 & AGS cell line & $\begin{array}{l}\text { Inhibited prolifera- } \\
\text { tion and migra- } \\
\text { tion }\end{array}$ \\
\hline Niu [116] & 2019 & Ovarian & miR-338-3p & WNT2B & $\begin{array}{l}54 \text { NT SKOV3, } \\
\text { A2780, and } \\
\text { IOSE- } 80 \text { cell } \\
\text { lines }\end{array}$ & $\begin{array}{l}\text { Induced cisplatin } \\
\text { response }\end{array}$ \\
\hline Xue [120] & 2014 & Colorectal & miR-338-3p & $\mathrm{SMO}$ & $\begin{array}{l}40 \text { NT HT29, } \\
\text { LOVO, Caco2, } \\
\text { and SW-620 } \\
\text { cell lines }\end{array}$ & $\begin{array}{l}\text { Inhibited cell } \\
\text { migration }\end{array}$ \\
\hline Huang [121] & 2011 & Liver & miR-338-3p & $\mathrm{SMO}$ & $\begin{array}{l}36 \text { NT Hep3B, SK- } \\
\text { HEP-1, Huh7, } \\
\text { Bel-7402, and } \\
\text { SMMC-7721 } \\
\text { cell lines }\end{array}$ & $\begin{array}{l}\text { Inhibited tumor } \\
\text { invasion }\end{array}$ \\
\hline Guo [124] & 2014 & Gastric & miR-338-3p & PREX2a & $\begin{array}{l}53 \text { NT AGS and } \\
\text { BGC-823 cell } \\
\text { lines }\end{array}$ & $\begin{array}{l}\text { Inhibited tumor } \\
\text { progression }\end{array}$ \\
\hline Chen [125] & 2013 & Neuroblastoma & miR-338-3p & PREX2a & $\begin{array}{l}18 \text { NT SH-SY5Y } \\
\text { cell line }\end{array}$ & $\begin{array}{l}\text { Inhibited cell } \\
\text { proliferation and } \\
\text { migration }\end{array}$ \\
\hline Besse [128] & 2016 & Glioblastoma & miR-338-5p & NDFIP1, PPP2R5a & $\begin{array}{l}40 \text { NT A } 172 \text {, } \\
\text { T98G, and } \\
\text { U87MG cell } \\
\text { lines }\end{array}$ & $\begin{array}{l}\text { Inhibited cell } \\
\text { proliferation }\end{array}$ \\
\hline Liu [132] & 2019 & Lung & miR-338-3p & AKT & A549 cell line & $\begin{array}{l}\text { Inhibited cell } \\
\text { proliferation }\end{array}$ \\
\hline Sui [133] & 2017 & Thyroid & miR-338-3p & AKT3 & $\begin{array}{l}48 \text { NT } 8505 c \text {, } \\
\text { TPC-1, and } \\
\text { SW1736 cell } \\
\text { lines }\end{array}$ & $\begin{array}{l}\text { Inhibited cell } \\
\text { proliferation, } \\
\text { migration, and } \\
\text { in vivo growth }\end{array}$ \\
\hline Lu [137] & 2018 & Cervical & miR-338-3p & ATF2 & $\begin{array}{l}30 \text { NT Siha, HeLa, } \\
\text { C33A, and } \\
\text { Me180 cell } \\
\text { lines }\end{array}$ & $\begin{array}{l}\text { Inhibited } \\
\text { autophagy }\end{array}$ \\
\hline Chu [141] & 2019 & Colorectal & miR-338-5p & PIK3C3 & $\begin{array}{l}66 \text { NT SW480 } \\
\text { and HCT166 } \\
\text { cell lines }\end{array}$ & $\begin{array}{l}\text { Induced tumor } \\
\text { invasion }\end{array}$ \\
\hline Zhang [145] & 2017 & Lung & miR-338-3p & IRS2 & $\begin{array}{l}40 \text { NT A549, } \\
\text { H1299, SPCA1, } \\
\text { and H358 cell } \\
\text { lines }\end{array}$ & $\begin{array}{l}\text { Inhibited cell } \\
\text { proliferation and } \\
\text { migration }\end{array}$ \\
\hline Wang [147] & 2015 & Liver & miR-338-3p & FOXP4 & $\begin{array}{l}30 \text { NT HepG2 } \\
\text { and Hep3B cell } \\
\text { lines }\end{array}$ & $\begin{array}{l}\text { Inhibited cell } \\
\text { proliferation }\end{array}$ \\
\hline Tong [152] & 2017 & Renal & miR-338-3p & SOX4 & $\begin{array}{l}48 \text { NT 786-O, } \\
\text { ACHN, Caki-1, } \\
\text { and Caki-2 cell } \\
\text { lines }\end{array}$ & $\begin{array}{l}\text { Inhibited colony } \\
\text { formation and } \\
\text { cell migration }\end{array}$ \\
\hline
\end{tabular}


Table 1 (continued)

\begin{tabular}{|c|c|c|c|c|c|c|}
\hline Study & Year & Type & Gene & Target & Samples & Function \\
\hline $\operatorname{Jin}[154]$ & 2015 & Breast & miR-338-3p & SOX 4 & $\begin{array}{l}32 \text { NT MCF-7, } \\
\text { MDA-MB-231, } \\
\text { BT-549, and } \\
\text { MDA-MB-453 } \\
\text { cell lines }\end{array}$ & $\begin{array}{l}\text { Inhibited colony } \\
\text { formation, in vivo } \\
\text { growth, and cell } \\
\text { migration }\end{array}$ \\
\hline Huang [155] & 2015 & Gastric & miR-338-3p & ZEB2 & $\begin{array}{l}20 \text { NT AGS, } \\
\text { MKN-45, and } \\
\text { NCI-N87 cell } \\
\text { lines }\end{array}$ & Inhibited EMT \\
\hline Lu [157] & 2019 & Colorectal & miR-338-3p & MACC1 & $\begin{array}{l}15 \text { NT SW480 } \\
\text { and } 293 \text { T cell } \\
\text { lines }\end{array}$ & $\begin{array}{l}\text { Inhibited cell } \\
\text { proliferation and } \\
\text { migration }\end{array}$ \\
\hline Zhang [158] & 2019 & Melanoma & miR-338-3p & MACC1 & $\begin{array}{l}60 \text { NT A375 and } \\
\text { G361 cell lines }\end{array}$ & $\begin{array}{l}\text { Inhibited cell } \\
\text { proliferation and } \\
\text { migration }\end{array}$ \\
\hline Zou [159] & 2018 & Colorectal & miR-338-3p & MACC1 & $\begin{array}{l}98 \text { NT SW480, } \\
\text { SW620, HT29, } \\
\text { HCT116, and } \\
\text { SW1116 cell } \\
\text { lines }\end{array}$ & $\begin{array}{l}\text { Inhibited tumor } \\
\text { progression }\end{array}$ \\
\hline Zhang [160] & 2019 & Ovarian & miR-338-3p & MACC1 & $105 \mathrm{NT}$ & $\begin{array}{l}\text { Inhibited cell } \\
\text { proliferation and } \\
\text { migration }\end{array}$ \\
\hline Shang [161] & 2016 & Glioma & miR-338-3p & MACC1 & $\begin{array}{l}39 T \text { and } 17 \mathrm{~N} \\
\text { U251 and U87 } \\
\text { cell lines }\end{array}$ & $\begin{array}{l}\text { Induced cisplatin } \\
\text { sensitivity }\end{array}$ \\
\hline $\mathrm{He}$ [166] & 2020 & Breast & miR-338-3p & ZEB1 & $\begin{array}{l}148 \text { NT MCF7 } \\
\text { and HCC1937 } \\
\text { cell lines }\end{array}$ & $\begin{array}{l}\text { Inhibited cell } \\
\text { proliferation and } \\
\text { EMT }\end{array}$ \\
\hline Shan [167] & 2015 & Nasopharyngeal & miR-338-3p & HIFIA & $\begin{array}{l}5 \text { NT CNE-1, } \\
\text { CNE-2,5-8F, } \\
\text { and 6-10B cell } \\
\text { lines }\end{array}$ & $\begin{array}{l}\text { Inhibited cell } \\
\text { migration and } \\
\text { proliferation }\end{array}$ \\
\hline Xu [168] & 2014 & Liver & miR-338-3p & HIFIA & $\begin{array}{l}15 \text { NT HepG2, } \\
\text { SMMC-7721, } \\
\text { BEK-7402, } \\
\text { Hep3B, and } \\
\text { Huh7 cell lines }\end{array}$ & $\begin{array}{l}\text { Induced sorafenib } \\
\text { response }\end{array}$ \\
\hline $\mathrm{He}$ [170] & 2020 & Lung & miR-338-3p & NFATC1 & $\begin{array}{l}20 \text { NT A549, } \\
\text { H1650, SPCA-1, } \\
\text { H460, H226, } \\
\text { and H1299 cell } \\
\text { lines }\end{array}$ & $\begin{array}{l}\text { Inhibited cell } \\
\text { proliferation }\end{array}$ \\
\hline Zhang [174] & 2019 & Bladder & miR-338-3p & ETS1 & $\begin{array}{l}39 \text { NT J82, 5637, } \\
\text { and T24 cell } \\
\text { lines }\end{array}$ & $\begin{array}{l}\text { Inhibited cell } \\
\text { proliferation and } \\
\text { EMT }\end{array}$ \\
\hline Li [176] & 2018 & Glioma & miR-338-5p & TSHZ3 & $\begin{array}{l}35 \text { NT U87 and } \\
\text { U251 cell lines }\end{array}$ & $\begin{array}{l}\text { Increased invasive- } \\
\text { ness }\end{array}$ \\
\hline Wen [178] & 2015 & Ovarian & miR-338-3p & RUNX2 & $\begin{array}{l}54 \text { NT SKOV3, } \\
\text { OVCAR3, and } \\
\text { A2780 cell lines }\end{array}$ & $\begin{array}{l}\text { Inhibited cell } \\
\text { proliferation, } \\
\text { migration, and } \\
\text { in vivo growth }\end{array}$ \\
\hline Duan [181] & 2019 & Breast & miR-338-3p & MORC4 & $\begin{array}{l}30 \text { NT MCF7 and } \\
\text { MDA-MB-231 } \\
\text { cell lines }\end{array}$ & $\begin{array}{l}\text { Inhibited cell } \\
\text { migration }\end{array}$ \\
\hline
\end{tabular}


Table 1 (continued)

\begin{tabular}{|c|c|c|c|c|c|c|}
\hline Study & Year & Type & Gene & Target & Samples & Function \\
\hline Li [185] & 2013 & Gastric & miR-338-3p & SSX2IP & $\begin{array}{l}66 \text { NT SGC-7901, } \\
\text { NCI-N87, } \\
\text { BGC-823, AGS, } \\
\text { KATO-III, SNU-1, } \\
\text { MKN-28, and } \\
\text { MKN-45 cell } \\
\text { lines }\end{array}$ & $\begin{array}{l}\text { Inhibited cell } \\
\text { proliferation anc } \\
\text { in vivo growth }\end{array}$ \\
\hline Lei [191] & 2017 & Glioblastoma & miR-338-5p & EFEMP1 & $\begin{array}{l}15 \text { NT U251, } \\
\text { A172, U-118, } \\
\text { and U87 cell } \\
\text { lines }\end{array}$ & $\begin{array}{l}\text { Inhibited cell } \\
\text { proliferation anc } \\
\text { migration }\end{array}$ \\
\hline Chen [197] & 2016 & Lung & miR-338-3p & ITGB3 & $\begin{array}{l}115 \text { NT A549, } \\
\text { NCI-H292, } \\
\text { NCI-H460, } \\
\text { NCI-H446, and } \\
\text { NCl-H1299 cell } \\
\text { lines }\end{array}$ & $\begin{array}{l}\text { Inhibited tumor } \\
\text { invasion }\end{array}$ \\
\hline Li [200] & 2018 & Renal & miR-338-3p & $\mathrm{KIFC1}$ & $\begin{array}{l}58 \text { NT 786-O, } \\
\text { 769-P, and } \\
\text { OS-RC-2 cell } \\
\text { lines }\end{array}$ & $\begin{array}{l}\text { Inhibited cell } \\
\text { proliferation anc } \\
\text { migration }\end{array}$ \\
\hline Cao [202] & 2018 & Osteosarcoma & miR-338-3p & AHSA1 & $\begin{array}{l}20 \text { NT MG-63, } \\
\text { Saos2, and HOS } \\
\text { cell lines }\end{array}$ & $\begin{array}{l}\text { Inhibited EMT and } \\
\text { invasion }\end{array}$ \\
\hline Xiao [207] & 2018 & Liver & miR-338-3p & SPHK2 & $\begin{array}{l}\text { 39T and 21N } \\
\text { HepG2, SMMC- } \\
7721 \text {, and } \\
\text { BEL7402 cell } \\
\text { lines }\end{array}$ & $\begin{array}{l}\text { Inhibited cell } \\
\text { proliferation }\end{array}$ \\
\hline Zhang [209] & 2017 & Lung & miR-338-3p & SPHK2 & $\begin{array}{l}34 \text { NT H460, } \\
\text { H1299, A549, } \\
\text { SPC-A-1, and } \\
\text { Calu-3 cell lines }\end{array}$ & $\begin{array}{l}\text { Inhibited cell } \\
\text { proliferation }\end{array}$ \\
\hline Han [216] & 2017 & Glioblastoma & miR-338-3p & PKM2 & $\begin{array}{l}\text { U87, LN229, and } \\
\text { SNB19 cell lines }\end{array}$ & $\begin{array}{l}\text { Inhibited cell } \\
\text { proliferation }\end{array}$ \\
\hline Zhang [217] & 2016 & Ovarian & miR-338-3p & PKM2 & $\begin{array}{l}\mathrm{HO}-890, \mathrm{~A} 2780, \\
\mathrm{CoC1}, \mathrm{CoC} 2, \\
\text { SKOV3, and } \\
\text { Caov-3 cell } \\
\text { lines }\end{array}$ & $\begin{array}{l}\text { Inhibited cell } \\
\text { proliferation }\end{array}$ \\
\hline Sun [220] & 2018 & Gastric & miR-338-3p & PTP1B & $\begin{array}{l}12 \text { NT MKN-45 } \\
\text { and MGC-803 } \\
\text { cell lines }\end{array}$ & $\begin{array}{l}\text { Inhibited cell } \\
\text { proliferation }\end{array}$ \\
\hline
\end{tabular}

*Normal and Tumor tissues

margins. It regulated lung tumor cell proliferation and migration via $R A B 14$ upregulation following miR338-3p sponging. There were also associations between circ-0000326 upregulation, $\mathrm{T}$ stage, $\mathrm{N}$ stage, and tumor grade of differentiation [35]. RAB23 belongs to the Rab GTPase family involved in vesicular transportation and endocytosis. It functions as an oncogene in many solid tumors such as bladder (BCa) and prostate (PCa) cancers. RAB23 induced BCa cell proliferation via the NF- $\mathrm{kB}$ and integrin $\beta 1 /$ Rac1 axis, and induced cisplatin resistance by the Shh-Gli-ABCG2 axis [36, 37]. It was reported that circHIPK3 silencing significantly reduced thyroid cancer (TC) cell proliferation and migration. It upregulated $R A B 23$ via miR-338-3p sponging in TC cells [38]. FOXP1 is a developmental transcription factor involved in embryogenesis and tumorigenesis. There was circ_104566 upregulation in high-grade compared with low-grade hepatocellular 
carcinoma (HCC) tumors, introducing a direct association between circ_104566 and TNM stage. Circ_104566 upregulation was also correlated with shorter overall survival that referred to the prognostic role of this marker in HCC. Circ_104566 silencing reduced HCC tumor cell progression, whereas it increased apoptosis through the miR-338-3p/FOXP1 axis [39]. Smoothened (SMO) is a G protein coupled receptor of the hedgehog signaling pathway that activates GLI1 to promote cell cycle progression and migration [40]. It was shown that there was circSMO742 upregulation in glioma cells in comparison with normal cells, which induced cell proliferation and inhibited apoptosis via miR-338-3p sponging and SMO upregulation [41]. HN1 is a negative regulator of AKT-mediated GSK3B signaling. It promotes CTNNB1 phosphorylation and degradation via GSK3B activation, resulting in APC/CTNNB1/GSK3B complex inhibition. It also suppresses the AR-signaling pathway by receptor degradation [42]. Circ_0000092 silencing reduced the levels of HN1 expression by miR-338-3p upregulation, which resulted in reduced HCC tumor progression. There was also circ_0000092 upregulation while there was miR-338-3p downregulation in HCC samples [43]. Hypoxia upregulates HIFs by stabilization of HIF1A subunits, which has critical functions during tumor angiogenesis and chemo-radio resistance [44, 45]. HIF1A and hypoxia-related miRNAs are involved in clinical outcomes of cancer patients [46]. There was circ-HIPK3 upregulation in cervical cancer (CC) cells and tissues. Circ-HIPK3 upregulated HIF1A by miR338-3p sponging in CC [47]. It was observed that circ-HIPK3 upregulation by HIF-2 $\alpha$ increased GC cell migration and invasion through the miR-338-3p/miR-653-5p/NPR1 axis. There was also circ-HIPK3 upregulation in gastric cancer (GC) tissues in comparison with normal margins [48]. Tyrosine phosphatase functions as a regulator of protein folding in endoplasmic reticulum. It was observed that there was circCCDC66 upregulation in osteosarcoma (OS) tissues compared with normal tissues, which was associated with relapse and metastasis. CircCCDC66 silencing also suppressed OS cell proliferation and metastasis via the miR-338-3p/PTP1B axis [49]. CDH1 is a $\mathrm{Ca}^{2+}$-dependent cell adhesion factor participating in cell motility and proliferation. Significant circ0137008 downregulation was observed in colorectal cancer (CRC) tissues and cell lines. It sponged the miR-338-5p to inhibit colorectal tumor cell proliferation and migration through $C D H 1$ upregulation [50].

\section{Long non-coding RNA}

LncRNAs are a type of ncRNAs longer than 200 nucleotides that have pivotal regulatory roles in cell proliferation, apoptosis, and angiogenesis [51, 52]. LncRNAs mainly function as competing endogenous RNAs (ceRNAs) to regulate mRNA through miRNAs sponging [53]. Cystatins are considered as inhibitors of $\mathrm{C} 1$ cysteine proteases in various cellular processes and disorders [54]. Cystatin $\mathrm{C}(\mathrm{Cys} C)$ triggers caspase-mediated apoptosis by cathepsin targeting [55]. It was reported that there was miR-338 downregulation in $30 \%$ of a sample of esophageal squamous cell carcinoma (ESCC) tissues in comparison with normal margins. Significant $\mathrm{CysC}$ protein upregulation was also observed in ESCC tissues that induced tumor cell growth, while inhibiting apoptosis. Moreover, there was significant SNHG1 upregulation in ESCC tissues compared with normal margins that inhibited cell apoptosis and induced proliferation through miR-338-3p sponging [56]. Polo-like kinases (PLKs) are important regulators of various cellular 
processes such as the cell cycle, centrosome duplication, and cell motility [57, 58]. Pololike kinase 4 (PLK4) is involved in centriole duplication and cell cycle progression [59]. SNHG1 induced neuroblastoma cell proliferation and migration by miR-338-3p sponging resulting in PLK4 upregulation [60]. SNHG16 upregulation is also associated with drug resistance and tumor progression in various cancers [61-63]. It was reported that there was significant SNHG16 upregulation in cisplatin-resistant NB cells and tissues. SNHG16 upregulated PLK4 through miR-338-3p sponging in cisplatin-resistant NB cells. The SNHG16/PLK4/miR-338-3p axis also activated the PI3K/AKT signaling pathway in NB cells [64]. RAB14 is a member of the GTPases that has a pivotal role in intracellular membrane trafficking between Golgi and endosomes. FOS is a leucine zipper DNA binding protein that forms a heterodimer transcriptional complex with the JUN family to regulate cell proliferation, apoptosis, and differentiation. SNHG15 upregulation was observed in CRC tissues compared with normal margins that were associated with poor prognosis. It promoted CRC cell proliferation while suppressing apoptosis by miR-338-3p sponging, which resulted in FOS and RAB14 upregulation [65]. As a critical regulator of TGF $\beta$ signaling, FKBP1A prevents TGF $\beta$ receptor activation in ligand absence. There were increased levels of SNHG15 expression in PCa cells. SNHG15 silencing reduced PCa cell proliferation and the EMT process. It seems that SNHG15 has oncogenic roles by regulation of the FKBP1A/miR338-3p axis in PCa cells [66].

Epithelial ovarian cancer (EOC) represents about $90 \%$ of all ovarian cancers (OC) [67]. Conventional therapeutic methods such as surgery and chemotherapy have been improved during recent years; however, there is still a poor prognosis in OC patients because of tumor metastasis and chemoresistance [68]. It was observed that there was LINC00460 upregulation in EOC tissues and cell lines that was correlated with FIGO stage, lower survival, and lymph node involvement. LINC00460 increased EOC cell proliferation and the EMT process partially through miR-338-3p regulation [69]. As a member of RAS GTPases, RAB25 is involved in intracellular membrane traffic and cell survival. It has a dual function and can play an oncogenic or tumor suppressor role based on cell context. LINC00173 increased PCa progression through RAB25 upregulation following miR-338-3p sponging [70]. It was reported that there was LINC00525 upregulation in glioma cell lines that regulated the tumor growth, migration, and EMT process through miR-338-3p sponging [71]. Homeobox proteins are developmental transcription factors with pivotal roles during morphogenesis and differentiation. LINC00689 upregulation was observed in GC tissues and cell lines. LINC00689 promoted GC cell growth and the EMT process by miR-338-3p targeting that resulted in HOXA3 overexpression [72].

$C R E B 3$ is a leucine zipper DNA binding protein that regulates cell proliferation by binding with cAMP-response element. CREB3 functions as a tumor suppressor of glioblastoma via inhibition of hypoxia-induced autophagy [73]. NEAT1 upregulated CREBRF via miR-338-3p sponging to suppress AML cell growth and migration, while induction of apoptosis [74]. CRNDE is an oncogenic lncRNA involved in tumor cell proliferation and migration [75]. There was significant CRNDE upregulation in NSCLC tissues and cell lines, which was directly correlated with lymph node involvement, advanced stage, and shorter overall survival. CRNDE silencing also inhibited tumor growth in nude mice. It induced NSCLC progression via miR-338-3p sponging [76]. IGF1R/IGF interaction 
activates Raf/MEK/ERK and P13K/AKT/mTOR signaling pathways, which are critical processes during tumor progression [77,78]. There was BANCR upregulation in ESCC cells and tissues. BANCR silencing reduced in vivo tumor growth, migration, and EMT via miR-338-3p sponging, which resulted in inhibition of the IGF1R/Raf/MEK/ERK pathway in ESCC cells [79]. It was reported that XLOC_O06390 inhibition significantly upregulated miR-338-3p, which resulted in PKM2 and EYA2 targeting in cervical tumors [80]. ADAM metallopeptidase domain 17 (ADAM17) is a metalloprotease that has pivotal roles in activation of TGF $\beta$, MAPK, and NOTCH signaling pathways [81]. There was significant SBF2-AS1 upregulation in NSCLC tissues and cell lines, which was correlated with distant metastasis, poor prognosis, and advanced stage. SBF2-AS1 increased NSCLC tumor growth probably through $A D A M 17$ upregulation following miR-338-3p sponging [82]. There was DSCAM-AS1 upregulation in HCC cell lines and tissues, which was correlated with poor prognosis. DSCAM-AS1 silencing reduced HCC cell proliferation, migration, and in vivo tumor growth. DSCAM-AS1 upregulated CCND1 and SOD via miR-338-3p sponging [83]. NRP1 is a co-receptor of VEGF functioning as ancogene in different tumors [84]. It was reported that there was OIP5-AS1 upregulation in oral squamous cell carcinoma (OSCC) tissue and cell lines in comparison with normal margins and cells. OIP5-AS1 significantly increased OSCC cell proliferation, migration, colony formation, and in vivo growth by regulation of the miR-338-3p/NRP1 axis [85].

\section{MAPK and EGFR signaling pathways}

Mitogen-activated protein kinase (MAPK) is a critical signaling pathway involved in regulation of cell proliferation, migration, differentiation, and apoptosis in response to extracellular signals [86]. Glioma tumors originate from glial progenitor or glial cells in the spine or brain [87]. FOXD1 is considered as a developmental transcription factor [88]. It was found that miR-338-5p suppressed MAPK signaling by FOXD1 downregulation to inhibit glioma cell proliferation and induce apoptosis [89]. MET transcriptional regulator (MACC1) is a transcription factor involved in tumor metastasis through the HGF/c-MET/MAPK axis. There was significant miR-338-3p downregulation in cervical cancer tissues that was associated with lymph node involvement, FIGO stage, and depth of invasion. MiR-338-3p inhibited MAPK signaling by $p 38$ and ERK1/2 downregulation in cervical tumor cells. Generally, miR-338-3p reduced cervical tumor cell proliferation through $M A C C 1$ targeting [90]. There were lower levels of miR-338-3p expressions in OS cell lines in comparison with normal cells. MiR-338-3p also decreased OS cell proliferation and migration, while it induced apoptosis via RUNX2 and CDK4 targeting and MAPK signaling pathway regulation [91]. EGFR belongs to the tyrosine kinase receptors, which are activated EGF ligands. Deregulation of EGFR signaling has been reported in tumor progression in different cancers [92]. MiRNAs are associated with drug resistance to anti-EGFR agents [93]. Neuropilin 1 (NRP1) as a coreceptor of growth factors is involved in tumor progression that affects tumor cell viability through EGFR and ErbB2 signaling pathways [94, 95]. NRP1 is widely upregulated in different solid tumors such as GC [96] and esophageal cancer [97]. It was observed that EGFR-TKI-mediated chemosensitivity was associated with the regulatory role of miR-338-3p on NRP1 in lung cancer. MiR-338-3p suppressed NSCLC colony formation and migration via NRP1 targeting [98]. It was reported that there was miR-338-3p downregulation in oral squamous cell 
carcinoma (OSCC) tissues. MiR-338-3p suppressed OSCC cell proliferation and invasion via NRP1 targeting [99]. NRP1 induces angiogenesis by p38 MAPK and ERK signaling pathways [100]. MiR-338-3p suppresses GC cell migration and proliferation, while it induces apoptosis through NRP1 targeting [96].

\section{WNT and hedgehog signaling pathways}

WNT signaling is a pivotal pathway that regulates various cellular processes during embryogenesis and tumorigenesis. Regarding the post-transcriptional regulatory roles of miRNAs, they can be suggested as modulators of protein components in the WNT pathway [101-103]. Gastric cancer (GC) is the most frequent gastrointestinal malignancy and the leading cause of cancer-related mortality in developing countries [104]. Despite recent progress in surgical and chemotherapeutic methods, there is still a low rate of 5-year survival due to advanced stage diagnosis [105]. SOX5 is a developmental transcription factor [106]. Significant miR-338-3p downregulation was observed in GC tissues and cell lines, which was associated with lymph node metastasis and advanced TNM stage. There was also cross-talk between WNT and hypoxia signaling, in which hypoxia promoted WNT signaling by the HIF-a/miR-338-3p/SOX5 axis. MiR-338-3p was downregulated by HIF1A [107]. EMT is critical process during tumor progression and metastasis in which epithelial cells gain mesenchymal features to have better abilities for invasion. This process is characterized by E-cadherin downregulation and vimentin upregulation [108-110]. The WNT signaling pathway regulates cell proliferation, polarity and death during embryogenesis [111]. It affects cell adhesion by E-cadherin downregulation that induces cell migration and EMT. It was reported that miR-338-3p inhibited GC proliferation and migration via EPHA2 targeting [112]. MACC1 regulates Met expression, which is a pivotal factor of HGF/Met and master regulator of EMT [113]. HGF/MET signaling promotes migration and angiogenesis in ovarian cancer (OC) [114]. It was reported that miR-338-3p reduced OC cell proliferation and migration by MACC1 or MET regulation. MiR-338-3p also downregulated MMP2/9, VIM, CTNNB1, and N-cadherin, while it upregulated E-cadherin, which resulted in inhibition of WNT and MEK/ERK signaling pathways [115]. WNT2B is a ligand for the frizzled family receptors that triggers the canonical WNT signaling pathway as an important regulatory pathway involved in cell proliferation and EMT. There was a correlation between cisplatin resistance and levels of miR-338-3p expression in OC patients. MiR-338-3p increased cisplatin sensitivity through WNT2B targeting in ovarian tumor cells [116].

The hedgehog $(\mathrm{Hh})$ signaling pathway is a conserved evolutionary embryonic signal transduction pathway from extracellular signals by specific receptors such as SMO and PTCH to the nucleus where it activates Gli transcription factors. Aberrant Hh signaling is associated with tumor progression [117]. Therefore, miRNAs have critical functions in regulation of Hh signaling during tumorigenesis. Activated SMO triggers a cytoplasmic cascade to activate GLI transcription factor that regulates cell proliferation, adhesion, and differentiation $[118,119]$. MiR-338-3p downregulation has been reported in CRC tissues, which was correlated with TNM stage and invasion. Advanced stage tumors had lower levels of miR-338-3p expression compared with primary stage tumors. MiR338-3p inhibited CRC invasion and migration via SMO targeting [120]. It was reported that there was miR-338-3p downregulation in liver tumor cells. MiR-338-3p reduced 
liver tumor cell migration via $S M O$ targeting. $S M O$ and $M M P 9$ levels of expressions were also correlated with advanced stages in HCC tissues. Therefore, miR-338-3p inhibited HCC invasiveness by downregulation of SMO-mediated MMP9 expression [121].

\section{PI3K/AKT signaling}

Phosphatidylinositol 3-kinase (PI3K) is a pivotal coordinator between extracellular signals and intracellular signaling which is activated by tyrosine kinase or G-protein coupled receptors. AKT is the main effector of PI3K that is negatively regulated by PTEN [122]. PREX2a belongs to the PIP3-dependent Rac exchanger (PREX) family of proteins associated with aggressive tumors [123]. It can directly suppress the lipid phosphatase activity of PTEN, resulting in PIP3 accumulation and increased AKT phosphorylation that induces cell cycle progression and growth during tumorigenesis. There was PREX2a upregulation in GC in comparison with normal margins. MiR-338-3p targeted PREX2a, resulting in PTEN activation and reduced AKT phosphorylation. MiR-338-3p also regulated $B C L-2$ and $B A X$ through induction of the PI3K/AKT signaling pathway [124]. MiR-338-3p reduced neuroblastoma tumor cell proliferation and migration via PREX2a targeting and PTEN/AKT regulation [125]. NDFIP1 is a ubiquitin E3 ligase that regulates PTEN stability and nuclear translocation along with RAB5. PTEN has a regulatory effect on the PI3K/Akt pathway, and also on E2F1 and RAD51 transcriptional functions. Moreover, PTEN is involved in double-strand break DNA repair [126, 127]. Significant miR-338-5p and 3p downregulation was reported in glioblastoma multiforme (GBM) patients in comparison with normal controls. MiR-338-5p significantly reduced GBM cell proliferation, while promoting apoptosis through NDFIP1 and PPP2R5a targeting [128]. AKT is a serine-threonine kinase that promotes tumor cell proliferation, inhibits apoptosis, and improves hypoxia resistance $[129,130]$. It is involved in CREB1 phosphorylation, which has a critical role in BCL2 and MCL1 upregulation [131]. It was found that miR-338-3p reduced lung tumor cell proliferation by inhibition of the AKT/ $\beta$ catenin pathway [132]. There was significant miR-338-3p downregulation in TC tissues compared with normal margins, which was inversely associated with stage and lymph node involvement. MiR-338-3p also significantly inhibited TC cell proliferation, motility, and in vivo growth via $A K T 3$ targeting .[133] It was reported that there was miR338-5p upregulation in melanoma tissues that was conversely associated with CD82 expression levels. MiR-338-5p induced melanoma cells proliferation and metastasis via CD82 targeting and p-AKT upregulation [134]. Autophagy is promoted by many factors, including growth factors and DNA damage, and it regulates many pathways [135]. As a double-edged sword autophagy can suppress tumor progression in the early stages. Increased autophagy stress of tumor cells is observed following anticancer therapy, which suggests that autophagy is a cellular protection mechanism [136]. MiR-338-3p suppresses autophagy in cervical tumor cells by ATF2 regulation via the PI3K/AKT/ mTOR signaling pathway [137]. PIK3C3 induces autophagy nucleation and inhibits EMT by degrading SNAIL and TWIST transcription factors in BC cells, leading to decreased cell migration and metastasis [138-140]. It was reported that miR-338-5p promoted CRC invasion by PIK3C3 targeting. It also repressed autophagy and inhibited degradation of snail and twist to induce tumor progression via EMT. Moreover, there was a direct association between levels of miR-338-5p expressions and clinicopathological 
tumor features including advanced stages and poor survival among CRC patients [141]. IRS2 is an adaptor protein for surface receptors such as IGF-1R that activates PI3K/AKT signaling to promote cell proliferation [142-144]. It was reported that there was miR338-3p downregulation in NSCLC tissues and cell lines in comparison with normal margins and cells, which was inversely correlated with advanced stage tumors with lymph node involvement. MiR-338-3p also reduced NSCLC cell proliferation and migration, while it increased apoptosis via IRS2 targeting [145].

\section{Transcription factors and regulators}

The forkhead box proteins are a family of transcription factors which are involved in regulation of cell cycle progression, cell migration, and angiogenesis. There is a complex association between miRNAs and function of forkhead box transcription factors [146]. FOXP4 is a member of the forkhead box (FOX) transcription factors with critical roles during embryogenesis and tumor progression. There was significant miR-338-3p downregulation in HCC tissues compared with normal margins. It also inhibited HCC cell proliferation via FOXP4 targeting [147]. SOX4 is a developmental transcription factor and critical regulator of EMT that is overexpressed in a variety of tumors [148, 149]. It regulates the miRNA machinery and various signaling pathways such as NOTCH, TGF$\beta, \mathrm{WNT}$, and hedgehog $[150,151]$. There was miR-338-3p downregulation in renal cell carcinoma (RCC) tissues that was correlated with lymph node involvement and TNM stage. MiR-338-3p also suppressed colony formation and migration of RCC through SOX4 targeting [152]. EMT can be promoted by SOX4 through EZH2 as a polycomb epigenetic regulator [153]. MiR-338-3p was downregulated in BC tissues, which was were correlated with advanced TNM stage and lymph node involvement. MiR-338-3p suppressed breast tumor cell colony formation, in vivo growth, and migration, while promoting apoptosis via SOX4 targeting [154].

MACC1 is an important transcription factor involved in EMT that promotes tumor cell migration and distant metastasis [155]. It also regulates the basolateral polarity of epithelial cells and angiogenesis [156]. There was significant downregulation of miR338-3p in CRC tissues. MiR-338-3p functions as a tumor suppressor through MACC1 inhibition in CRC [157]. It was observed that there was miR-338-3p downregulation in malignant melanoma (MM) tissues that was correlated with advanced TNM stages and lymph node involvement. MiR-338-3p reduced MM cell proliferation and migration through MACC1 targeting, resulting in E-cadherin upregulation and vimentin downregulation [158]. MiR-338-3p was downregulated in CRC cell lines and tissues compared with normal cells and margins, which was correlated with differentiation, TNM stage, and overall survival. It inhibited CRC progression by MACC1 targeting [159]. Another study reported that there were significant miR-338-3p downregulation and $M A C C 1$ upregulation in EOC tissues compared with normal tissues, which were associated with advanced stage, high grade, recurrence, and metastatic lymph nodes. EOC patients with low levels of miR-338-3p expression also had significantly shorter overall survival [160]. miR-338-3p downregulation was observed in glioma tissues, which was inversely associated with histological grades. MiR-338-3p also inhibited cell proliferation, while it induced apoptosis and cisplatin sensitivity by MACC1 targeting [161]. 
Tumor hypoxia is one of the main reasons for chemoradiotherapeutic resistance, which affects tumor invasiveness and poor prognosis [162]. HIF1A is a transcription factor with critical functions in the hypoxia response by induction of metastasis and angiogenesis [163-165]. It was reported that there was miR-338-3p downregulation in BC tissue and cells. MiR-338-3p suppressed breast tumor cell proliferation and EMT through ZEB2 targeting. HIF1A also reduced the levels of miR-338-3p expression [166]. It was found that miR-338-3p inhibited cell migration and proliferation by $H I F 1 A$ targeting in nasopharyngeal carcinoma (NPC) cells. There was also miR-338-3p downregulation in NPC tissues [167]. Another study showed that there was significant miR-338-3p downregulation in HCC tissues compared with normal tissues. MiR-338-3p inhibited HCC cell viability, while it increased the sorafenib response and apoptosis rate through HIF1A targeting [168].

NFATc1 is a DNA binding transcription complex with critical roles in stimulation of production of cytokines such as IL-2 and IL-4 in T-cells. It can also regulate activation and apoptosis of T-cells, lymphoid, and non-lymphoid cells [169]. It was reported that there was significant NFATc1 upregulation in NSCLC tissues. NFATc1 silencing increased the levels of $C C N D 1$ and $C D K 4$ expression, whereas it downregulated $p 27$. Moreover, NFATc1 silencing upregulated $C D H 1$ and downregulated $C D H 2$ and vimentin. MiR-338 reduced cell proliferation and EMT via NFATc1 targeting in NSCLC cells [170]. $Z E B 1$ is a zinc finger E-box-binding transcription factor that functions as a transcriptional suppressor in various genes such as $I L-2$ and $C D H 1$. It recruits the SMARCA4/BRG1 complex to represses CDH1 during EMT [171, 172]. There was miR338-3p downregulation in advanced GC tumors. MiR-338-3p reduced GC cell migration and EMT through ZEB2 targeting and MACC1/MET/AKT axis inhibition. MiR-338-3p was inversely associated with $C D H 2, M A C C 1$, and $Z E B 2$, while directly associated with CDH1 expression in GC samples [155]. ETS1 is a transcription factor involved in tumor metastasis [173]. There was miR-338-3p downregulation in bladder cancer (BCa), which was correlated with TNM stage and lymph node involvement. MiR-338-3p reduced BCa cell proliferation and EMT via ETS1 inhibition [174]. TSHZ3 is a critical developmental transcription factor during muscle cell differentiation [175]. An inverse association was found between levels of miR-338-5p and TSHZ3 expression in high-grade astrocytic gliomas. MiR-338-5p increased glioma invasiveness by TSHZ3 targeting [176]. RUNX2 is a developmental transcription factor involved in normal bone development [177]. There was significant miR-338-3p downregulation in EOC tissues compared with normal margins that was inversely correlated with lymph node metastasis, advanced FIGO stage, and grade. MiR-338-3p significantly reduced EOC cell proliferation, in vivo tumor growth, and migration through RUNX2 targeting and inhibition of the PI3K/AKT pathway [178]. Baicalin is an anti-proliferative and anti-inflammatory alkaloid used in treatment of cancers or disorders [179]. MORC4 functions in generation of nuclear bodies and is involved in cell cycle progression. It is also involved in chemoresistance by activation of the transcription factor STAT3 [180]. Baicalin reduced the levels of MORC4 following miR-338-3p upregulation, which resulted in increased apoptosis and reduced migration in BC cells [181]. Methylation is an important epigenetic mechanism during tumor progression that promotes tumor growth via hypermethylation and hypomethylation of the CpG island promoter sequences in tumor suppressors and oncogenes, 
respectively [182]. MECP2 is a key member of the DNA methylation machinery involved in neural development [183]. There was also MECP2 upregulation in GC which promoted cell proliferation in vitro/vivo. MECP2 reduced the levels of miR-338 expression by binding with methylated $\mathrm{CPG}$ islands in the promoter sequence. Significant miR338-5p downregulation was observed in GC tissues that inhibited cell growth through BMI1 targeting as a proto-oncogene involved in transcriptional regulation [184].

\section{Structural and adhesion factors}

SSX2IP is a member of the adhesion system that is involved in cell-cell adherens junctions through alpha-actinin. It also regulates cell motility in response to PDGF by activation of Rac signaling. It was found that there was miR-338-3p downregulation in GC tissues in comparison with normal margins. MiR-338-3p reduced GC cell proliferation and in vivo growth, while it induced apoptosis through SSX2IP targeting. MiR-338-3p downregulation was correlated with metastatic lymph nodes, larger tumor size, and advanced tumor stage [185]. EGF containing fibulin extracellular matrix protein 1 (EFEMP1) belongs to the fibulin family of extracellular matrix (ECM) glycoproteins that regulate cell adhesion, growth, and movement [186]. It also maintains tissue hemostasis by regulation of the tissue inhibitors of matrix metalloproteinase (TIMMPs) and MMPs [187, 188]. EFEMP1 exerts its tumor suppressor activity by suppression of tumor angiogenesis and inhibition of the EGFR/AKT signaling pathway $[189,190]$. It was reported that miR-338-5p was downregulated in GBM tissues. MiR-338-5p also reduced GBM cell proliferation and migration, while it significantly induced apoptosis through EFEMP1 inhibition [191]. ITGB3 is a receptor of various ECM proteins including fibronectin, laminin, $M M P$-2, and thrombospondin [192]. It regulates several signaling pathways, such as NRG1-ERBB, FGF1, and IGF1 signaling [193-195]. Therefore, it can be introduced as a pivotal regulator of angiogenesis, adhesion, and metastasis [196]. There was an inverse association between levels of miR-338 and ITGB3 expression in lung tumor tissues [197]. KIFC1 is a kinesin motor protein involved in clustering of extra centrosomes in tumor cells [198]. It is required for tumor cell survival and invasion by regulation of excess centrosomes to generate progeny cells and maintenance toward apoptosis-mediated aneuploidy [199]. KIFC1 silencing reduces $\mathrm{RCC}$ cell proliferation, migration, and in vivo growth by inhibition of PI3K/AKT signaling and downregulation of MMP-2 and VEGF. MiR-338-3p reduced cell migration and proliferation by KIFC1 targeting. Also KIFC1 upregulation was significantly correlated with advanced $\mathrm{pT}$ and $\mathrm{pTNM}$ stage and larger tumor size in RCC tissues [200]. AHSA1 is a chaperone involved in maturation, degradation, and stabilization of oncogenes [201]. There was miR-338-3p downregulation in osteosarcoma (OS) cell lines and tissues. MiR-338-3p suppressed viability, EMT, and invasion of OS cells through AHSA1 targeting [202]. RAB14 belongs to the RAS family of GTPases involved in intracellular membrane traffic during embryogenesis. MiR-338-3p downregulation was observed in NSCLC tissues compared with normal margins, which was directly correlated with differentiation, and conversely associated with stage and lymph node involvement. MiR-338-3p inhibited NSCLC cell proliferation, while it promoted apoptosis through RAB14 targeting [203]. 


\section{Kinases and phosphatases}

Sphingolipids are a group of hydrophobic molecules including sphingoid-base phosphates and sphingoid bases that are associated with cell proliferation and apoptosis [204, 205]. Sphingosine kinase 2 (SphK2) is involved in formation of sphingosine-1-phosphate (SPP) as a lipid mediator in cellular functions. It also participates in transcriptional regulation by $H D A C 1$ and $H D A C 2$ suppression and histone acetylation [206]. It regulates ATP and ROS levels in dopaminergic neurons. Significant miR-338-3p downregulation was observed in liver tumor tissues in comparison with normal margins. MiR-338-3p exerts its tumor suppressor role by SPHK2 targeting in liver tumor cells [207]. MiR338-3p downregulation was reported in colorectal and gastric cancers [155, 203, 208]. There was miR-338-3p downregulation in NSCLC tissues that was significantly associated with stage. MiR-338-3p also reduced NSCLC cell proliferation and promoted apoptosis via SPHK2 targeting [209]. Pyruvate kinase M2 (PKM2) is responsible for ATP production via regulation of aerobic glycolysis [210, 211]. Despite the metabolic functions, PKM2 inhibits mTOR-mediated tumor progression, and also it is involved in cell cycle regulation and drug resistance [212,213]. PKM2 regulates the WNT pathway by regulation of CTNNB1 transcriptional activity and also functions as a transcriptional regulator by phosphorylation of histone $\mathrm{H} 3[214,215]$. It was reported that there was a rising trend of PKM2 expression levels with glioma grade in which PKM2-overexpressed glioblastoma tumors had worse outcomes. PKM2 ectopic expression promoted glioma cell proliferation and metabolism. MiR-338-3p suppressed glioma cell proliferation by PKM2 targeting [216]. There was miR338-3p downregulation in OC tissues in comparison with normal margins. MiR-338-3p also suppressed cell proliferation and ATP production in OC cells through PKM2 targeting [217]. Protein-tyrosine phosphatase 1B (PTP1B) is a tyrosine phosphatase involved in regulation of leptin and insulin signaling pathways [218]. It also functions as a tumor suppressor by dephosphorylation and inactivation of oncogenic kinases. MiR-338-3p is a brain-specific miRNA participating in regulation of axonal respiration [156, 219]. There was an inverse association between levels of miR-338-3p and PTP1B expression in GC tissues. MiR-338-3p exerted its tumor suppressor role through $P T P 1 B$ targeting in GC. PTP1B upregulation also significantly increased the levels of pAKT and p-ERK1/2 expression in GC tumor cells [220].

\section{Conclusions}

Since the mammalian miRNAs and their target mRNA sequences are not perfectly complementary, various mRNAs can be targeted by a specific miRNA. Therefore, there is a great challenge to clarify the precise molecular mechanisms of specific miRNAs. Understanding the molecular mechanism of miRNAs is important to introduce novel therapeutic strategies for human disorders and malignancies. However, there are contradictory reports about the role of miRNAs in different malignancies, which may be related to the use of computational and predictive methods instead of experimental verification. Moreover, the protein levels do not always exactly reflect the levels of mRNA expression. Therefore, miRNA studies should always be accompanied by protein assessments [221]. In the present review, we have summarized miR-338 target genes and associated signaling pathways to clarify the molecular mechanisms of miR-338 during tumor 
progression. It was observed that miR-338 mainly functions as a tumor suppressor in different cancers. There were also significant associations between miR-338 and other non-coding RNAs including circular and long non-coding RNAs in tumor cells.

\begin{abstract}
Abbreviations
miRNAs: MicroRNAs; ncRNAs: Non-coding RNAs; IncRNAs: Long non-coding RNAs; miRNAs: MicroRNAs; circRNAs: Circular RNAs; RISC: RNA induced silencing complex; EMT: Epithelial mesenchymal transition; NSCLC: Non-small cell lung cancer; RCC: Renal cell carcinoma; cCRCC: Clear cell RCC; CAV1: Caveolin-1; BRD4: Bromodomain containing 4; MM: Multiple myeloma; TC: Thyroid cancer; HCC: Hepatocellular carcinoma; SMO: Smoothened; CC: Cervical cancer; CRC: Colorectal cancer; PLKs: Polo-like kinases; PLK4: Polo like kinase 4; PCa: Prostate cancer; EOC: Epithelial ovarian cancer; ADAM17: ADAM metallopeptidase domain 17; VEGF:Vascular endothelial growth factor; EGFR: Epidermal growth factor receptor; NRP1: Neuropilin 1; GC: Gastric cancer; OC: Ovarian cancer; Hh: Hedgehog; PI3K: Phosphatidylinositol 3-kinase; PREX: PIP3-dependent Rac exchanger; FOX: Forkhead box; MM: Malignant melanoma; NPC: Nasopharyngeal carcinoma; ECM: Extracellular matrix; TIMMPs: Tissue inhibitors of matrix metalloproteinase; OS: Osteosarcoma; SphK2: Sphingosine kinase 2; SPP: Sphingosine-1-phosphate; PKM2: Pyruvate kinase M2; PTP1B: Protein-tyrosine phosphatase 1B; CysC: Cystatin C; CysC: Oral squamous cell carcinoma; CysC: Osteosarcoma; GC: Gastric cancer; MACC1: MET transcriptional regulator; EFEMP1: EGF containing fibulin extracellular matrix protein 1.
\end{abstract}

Acknowledgements

Not applicable.

Authors' contributions

MM prepared, revised, and edited the manuscript. All authors read and approved the final manuscript.

Funding

Not applicable.

Availability of data and materials

The datasets used and/or analyzed during the current study are available from the corresponding author on reasonable request.

\title{
Declarations
}

Ethics approval and consent to participate

Not applicable.

\section{Consent for publication}

Not applicable.

\section{Competing interests}

The authors declare that they have no competing interests.

Received: 16 January 2021 Accepted: 25 March 2021

Published online: 07 April 2021

\section{References}

1. Chen J, Zhang K, Xu Y, Gao Y, Li C, Wang R, et al. The role of microRNA-26a in human cancer progression and clinical application. Tumour Biol. 2016;37(6):7095-108

2. Nana-Sinkam SP, Croce CM. Non-coding RNAs in cancer initiation and progression and as novel biomarkers. Mol Oncol. 2011:5(6):483-91.

3. Zangouei AS, Rahimi HR, Mojarrad M, Moghbeli M. Non coding RNAs as the critical factors in chemo resistance of bladder tumor cells. Diagn Pathol. 2020;15(1):136.

4. Rahmani Z, Mojarrad M, Moghbeli M. Long non-coding RNAs as the critical factors during tumor progressions among Iranian population: an overview. Cell Biosci. 2020;10:6.

5. Bartel DP. MicroRNAs: genomics, biogenesis, mechanism, and function. Cell. 2004;116(2):281-97.

6. Farazi TA, Spitzer Jl, Morozov P, Tuschl T. miRNAs in human cancer. J Pathol. 2011;223(2):102-15.

7. McManus MT. MicroRNAs and cancer. Semin Cancer Biol. 2003;13(4):253-8.

8. Shenouda SK, Alahari SK. MicroRNA function in cancer: oncogene or a tumor suppressor? Cancer Metastasis Rev. 2009;28(3-4):369-78.

9. Zhang B, Pan X, Cobb GP, Anderson TA. microRNAs as oncogenes and tumor suppressors. Dev Biol. 2007;302(1):1-12

10. Yu DC, Li QG, Ding XW, Ding YT. Circulating microRNAs: potential biomarkers for cancer. Int J Mol Sci. 2011:12(3):2055-63

11. Cuk K, Zucknick M, Heil J, Madhavan D, Schott S, Turchinovich A, et al. Circulating microRNAs in plasma as early detection markers for breast cancer. Int J Cancer. 2013;132(7):1602-12.

12. Gorur A, Balci Fidanci S, Dogruer Unal N, Ayaz L, Akbayir S, Yildirim Yaroglu H, et al. Determination of plasma microRNA for early detection of gastric cancer. Mol Biol Rep. 2013;40(3):2091-6. 
13. Raghunath M, Patti R, Bannerman P, Lee CM, Baker S, Sutton LN, et al. A novel kinase, AATYK induces and promotes neuronal differentiation in a human neuroblastoma (SH-SY5Y) cell line. Brain Res Mol Brain Res. 2000;77(2):151-62.

14. Patop IL, Wust S, Kadener S. Past, present, and future of circRNAs. EMBO J. 2019;38(16):e100836.

15. Bach DH, Lee SK, Sood AK. Circular RNAs in cancer. Mol Therapy Nucleic Acids. 2019;16:118-29.

16. Jiang F, Shen X. Current prevalence status of gastric cancer and recent studies on the roles of circular RNAs and methods used to investigate circular RNAs. Cell Mol Biol Lett. 2019;24:53.

17. Chen W, Zheng R, Zeng H, Zhang S. The updated incidences and mortalities of major cancers in China, 2011. Chin J Cancer. 2015;34(11):502-7.

18. Saika K, Machii R. Cancer mortality attributable to tobacco in Asia based on the WHO Global Report. Jpn J Clin Oncol. 2012;42(10):985.

19. Siegel R, Naishadham D, Jemal A. Cancer statistics, 2013. CA Cancer J Clin. 2013;63(1):11-30.

20. Liu T, Song Z, Gai Y. Circular RNA circ_0001649 acts as a prognostic biomarker and inhibits NSCLC progression via sponging miR-331-3p and miR-338-5p. Biochem Biophys Res Commun. 2018;503(3):1503-9.

21. Hsieh JJ, Purdue MP, Signoretti S, Swanton C, Albiges L, Schmidinger M, et al. Renal cell carcinoma. Nat Rev Dis Primers. 2017:3:17009.

22. Muglia VF, Prando A. Renal cell carcinoma: histological classification and correlation with imaging findings. Radiol Bras. 2015;48(3):166-74.

23. Hwangbo C, Tae N, Lee S, Kim O, Park OK, Kim J, et al. Syntenin regulates TGF-beta1-induced Smad activation and the epithelial-to-mesenchymal transition by inhibiting caveolin-mediated TGF-beta type I receptor internalization. Oncogene. 2016;35(3):389-401.

24. Zhu Q, Zhan D, Zhu P, Chong Y, Yang Y. CircAKT1 acts as a sponge of miR-338-3p to facilitate clear cell renal cell carcinoma progression by up-regulating CAV1. Biochem Biophys Res Commun. 2020:532(4):584-90.

25. Patel MC, Debrosse M, Smith M, Dey A, Huynh W, Sarai N, et al. BRD4 coordinates recruitment of pause release factor P-TEFb and the pausing complex NELF/DSIF to regulate transcription elongation of interferon-stimulated genes. Mol Cell Biol. 2013;33(12):2497-507.

26. Wang R, Li Q, Helfer CM, Jiao J, You J. Bromodomain protein Brd4 associated with acetylated chromatin is important for maintenance of higher-order chromatin structure. J Biol Chem. 2012;287(14):10738-52.

27. Wu SY, Lee AY, Lai HT, Zhang H, Chiang CM. Phospho switch triggers Brd4 chromatin binding and activator recruitment for gene-specific targeting. Mol Cell. 2013;49(5):843-57.

28. Wang Y, Lin Q, Song C, Ma R, Li X. Circ_0007841 promotes the progression of multiple myeloma through targeting miR-338-3p/BRD4 signaling cascade. Cancer Cell Int. 2020;20:383.

29. Chien CW, Hou PC, Wu HC, Chang YL, Lin SC, Lin SC, et al. Targeting TYRO3 inhibits epithelial-mesenchymal transition and increases drug sensitivity in colon cancer. Oncogene. 2016;35(45):5872-81.

30. Qin A, Qian W. MicroRNA-7 inhibits colorectal cancer cell proliferation, migration and invasion via TYRO3 and phosphoinositide 3-kinase/protein B kinase/mammalian target of rapamycin pathway suppression. Int J Mol Med. 2018;42(5):2503-14

31. Smart SK, Vasileiadi E, Wang X, DeRyckere D, Graham DK. The emerging role of TYRO3 as a therapeutic target in cancer. Cancers (Basel). 2018;10(12).

32. Du J, Xu J, Chen J, Liu W, Wang P, Ye K. circRAE1 promotes colorectal cancer cell migration and invasion by modulating miR-338-3p/TYRO3 axis. Cancer Cell Int. 2020;20:430.

33. Guo B, Wang W, Zhao Z, Li Q, Zhou K, Zhao L, et al. Rab14 act as oncogene and induce proliferation of gastric cancer cells via AKT signaling pathway. PLoS ONE. 2017;12(1):e0170620.

34. Linford A, Yoshimura S, Nunes Bastos R, Langemeyer L, Gerondopoulos A, Rigden DJ, et al. Rab14 and its exchange factor FAM1 16 link endocytic recycling and adherens junction stability in migrating cells. Dev Cell. 2012;22(5):952-66.

35. Xu Y, Yu J, Huang Z, Fu B, Tao Y, Qi X, et al. Circular RNA hsa_circ_0000326 acts as a miR-338-3p sponge to facilitate lung adenocarcinoma progression. J Exp Clin Cancer Res: CR. 2020;39(1):57.

36. Chang J, Xu W, Liu G, Du X, Li X. Downregulation of Rab23 in prostate cancer inhibits tumor growth in vitro and in vivo. Oncol Res. 2017;25(2):241-8.

37. Jiang Y, Han Y, Sun C, Han C, Han N, Zhi W, et al. Rab23 is overexpressed in human bladder cancer and promotes cancer cell proliferation and invasion. Tumour Biol. 2016;37(6):8131-8.

38. Shu T, Yang L, Sun L, Lu J, Zhan X. CircHIPK3 promotes thyroid cancer tumorigenesis and invasion through the mirna-338-3p/RAB23 Axis. Med Princ Pract. 2020.

39. Liu G, Guo W, Rao M, Qin J, Hu F, Li K. circRNA hsa_circ_104566 Sponged miR-338-3p to promote hepatocellular carcinoma progression. Cell Transplant. 2020;29:963689720963948.

40. Yan GN, Lv YF, Yang L, Yao XH, Cui YH, Guo DY. Glioma stem cells enhance endothelial cell migration and proliferation via the Hedgehog pathway. Oncol Lett. 2013:6(5):1524-30.

41. Xiong Z, Zhou C, Wang L, Zhu R, Zhong L, Wan D, et al. Circular RNA SMO sponges miR-338-3p to promote the growth of glioma by enhancing the expression of SMO. Aging (Albany NY). 2019;11(24):12345-60.

42. Varisli L, Gonen-Korkmaz C, Syed HM, Bogurcu N, Debelec-Butuner B, Erbaykent-Tepedelen B, et al. Androgen regulated HN1 leads proteosomal degradation of androgen receptor (AR) and negatively influences AR mediated transactivation in prostate cells. Mol Cell Endocrinol. 2012;350(1):107-17.

43. Pu J, Wang J, Li W, Lu Y, Wu X, Long X, et al. hsa_circ_0000092 promotes hepatocellular carcinoma progression through up-regulating HN1 expression by binding to microRNA-338-3p. J Cell Mol Med. 2020.

44. Rankin EB, Giaccia AJ. Hypoxic control of metastasis. Science. 2016;352(6282):175-80.

45. Madanecki P, Kapoor N, Bebok Z, Ochocka R, Collawn JF, Bartoszewski R. Regulation of angiogenesis by hypoxia: the role of microRNA. Cell Mol Biol Lett. 2013;18(1):47-57.

46. Yang W, Ma J, Zhou W, Cao B, Zhou X, Zhang H, et al. Reciprocal regulations between miRNAs and HIF-1alpha in human cancers. Cell Mol Life Sci. 2019;76(3):453-71.

47. Qian W, Huang T, Feng W. Circular RNA HIPK3 promotes EMT of cervical cancer through sponging miR-338-3p to Up-regulate HIF-1alpha. Cancer Manag Res. 2020;12:177-87. 
48. Jin Y, Che X, Qu X, Li X, Lu W, Wu J, et al. CircHIPK3 promotes metastasis of gastric cancer via miR-653-5p/miR-3383p-NRP1 axis under a long-term hypoxic microenvironment. Front Oncol. 2020;10:1612.

49. Xiang D, Li Y, Lin Y. Circular RNA circCCDC66 contributes to malignant phenotype of osteosarcoma by sponging miR-338-3p to upregulate the expression of PTP1B. Biomed Res Int. 2020;2020:4637109.

50. Yang Z, Zhang J, Lu D, Sun Y, Zhao X, Wang X, et al. Hsa_circ_0137008 suppresses the malignant phenotype in colorectal cancer by acting as a microRNA-338-5p sponge. Cancer Cell Int. 2020;20:67.

51. Ponting CP, Oliver PL, Reik W. Evolution and functions of long noncoding RNAs. Cell. 2009;136(4):629-41.

52. Wu Z, Liu X, Liu L, Deng H, Zhang J, Xu Q, et al. Regulation of IncRNA expression. Cell Mol Biol Lett. 2014;19(4):561-75.

53. Lu G, Li Y, Ma Y, Lu J, Chen Y, Jiang Q, et al. Long noncoding RNA LINC00511 contributes to breast cancer tumourigenesis and stemness by inducing the miR-185-3p/E2F1/Nanog axis. J Exp Clin Cancer Res: CR. 2018;37(1):289.

54. Abrahamson M. Cystatins. Methods Enzymol. 1994;244:685-700.

55. Dikovskaya MA, Trunov AN, Chernykh W, Korolenko TA. Cystatin C and lactoferrin concentrations in biological fluids as possible prognostic factors in eye tumor development. Int J Circumpolar Health. 2013;72.

56. Yan Y, Fan Q, Wang L, Zhou Y, Li J, Zhou K. LncRNA Snhg1, a non-degradable sponge for miR-338, promotes expression of proto-oncogene CST3 in primary esophageal cancer cells. Oncotarget. 2017;8(22):35750-60.

57. Li Z, Dai K, Wang C, Song Y, Gu F, Liu F, et al. Expression of polo-like kinase 4(PLK4) in breast cancer and its response to Taxane-based neoadjuvant chemotherapy. J Cancer. 2016;7(9):1125-32.

58. Swallow CJ, Ko MA, Siddiqui NU, Hudson JW, Dennis JW. Sak/PIk4 and mitotic fidelity. Oncogene. 2005;24(2):306-12

59. Maniswami RR, Prashanth S, Karanth AV, Koushik S, Govindaraj H, Mullangi R, et al. PLK4: a link between centriole biogenesis and cancer. Expert Opin Ther Targets. 2018;22(1):59-73.

60. Zhang N, Liu FL, Ma TS, Zhang ZZJ. LnCRNA SNHG1 contributes to tumorigenesis and mechanism by targeting miR-338-3p to regulate PLK4 in human neuroblastoma. Eur Rev Med Pharmacol Sci. 2019;23(20):8971-83.

61. Cai C, Huo Q, Wang X, Chen B, Yang Q. SNHG16 contributes to breast cancer cell migration by competitively binding miR-98 with E2F5. Biochem Biophys Res Commun. 2017:485(2):272-8.

62. Lian D, Amin B, Du D, Yan W. Enhanced expression of the long non-coding RNA SNHG16 contributes to gastric cancer progression and metastasis. Cancer Biomarkers: Sect A Dis Markers. 2017;21(1):151-60.

63. Liu Y, Gu S, Li H, Wang J, Wei C, Liu Q. SNHG16 promotes osteosarcoma progression and enhances cisplatin resistance by sponging miR-16 to upregulate ATG4B expression. Biochem Biophys Res Commun. 2019;518(1):127-33.

64. Xu Z, Sun Y, Wang D, Sun H, Liu X. SNHG16 promotes tumorigenesis and cisplatin resistance by regulating miR338-3p/PLK4 pathway in neuroblastoma cells. Cancer Cell Int. 2020;20:236.

65. Li M, Bian Z, Jin G, Zhang J, Yao S, Feng Y, et al. LncRNA-SNHG15 enhances cell proliferation in colorectal cancer by inhibiting miR-338-3p. Cancer Med. 2019;8(5):2404-13.

66. Zhang Y, Zhang D, LV J, Wang S, Zhang Q. LnCRNA SNHG15 acts as an oncogene in prostate cancer by regulating miR-338-3p/FKBP1A axis. Gene. 2019;705:44-50.

67. Siegel RL, Miller KD, Jemal A. Cancer statistics, 2016. CA Cancer J Clin. 2016;66(1):7-30.

68. Basen-Engquist K. Ovarian cancer screening and psychosocial issues: relevance to clinical practice. Gynecol Oncol. 1997;65(2):195-6.

69. Liu X, Wen J, Wang H, Wang Y. Long non-coding RNA LINC00460 promotes epithelial ovarian cancer progression by regulating microRNA-338-3p. Biomed Pharmacother Biomed Pharmacother. 2018;108:1022-8.

70. $\mathrm{Hu} \mathrm{CH}$, Yang XJ, Yu L, Wang LY, Zhao XC, Han CH. Long non-coding RNA LINC00173 serves as sponge for miR-338-3p to promote prostate cancer progression via regulating Rab25. Eur Rev Med Pharmacol Sci. 2020;24(18):9290-302.

71. Wan Y, Liang F, Wei M, Liu Y. Long non-coding RNA LINC00525 regulates the proliferation and epithelial to mesenchymal transition of human glioma cells by sponging miR-338-3p. AMB Express. 2020;10(1):156.

72. Lu H, Zhang Q, Sun Y, Wu D, Liu L. LINC00689 induces gastric cancer progression via modulating the miR-338-3p/ HOXA3 axis. J Gene Med. 2020;22(12):e3275.

73. Xue H, Zhang J, Guo X, Wang J, Li J, Gao X, et al. CREBRF is a potent tumor suppressor of glioblastoma by blocking hypoxia-induced autophagy via the CREB3/ATG5 pathway. Int J Oncol. 2016;49(2):519-28.

74. Feng S, Liu N, Chen X, Liu Y, An J. Long non-coding RNA NEAT1/miR-338-3p axis impedes the progression of acute myeloid leukemia via regulating CREBRF. Cancer Cell Int. 2020;20:112.

75. Meng Y, Li Q, Li L, Ma R. The long non-coding RNA CRNDE promotes cervical cancer cell growth and metastasis. Biol Chem. 2017;399(1):93-100.

76. Jing $\mathrm{H}$, Xia $\mathrm{H}$, Qian M, Lv X. Long noncoding RNA CRNDE promotes non-small cell lung cancer progression via sponging microRNA-338-3p. Biomed Pharmacother Biomed Pharmacother. 2019;110:825-33.

77. Ma W, Zhang T, Pan J, Shi N, Fan Q, Wang L, et al. Assessment of insulin-like growth factor 1 receptor as an oncogene in esophageal squamous cell carcinoma and its potential implication in chemotherapy. Oncol Rep. 2014:32(4):1601-9.

78. Sharmila G, Bhat FA, Arunkumar R, Elumalai P, Raja Singh P, Senthilkumar K, et al. Chemopreventive effect of quercetin, a natural dietary flavonoid on prostate cancer in in vivo model. Clin Nutr. 2014;33(4):718-26.

79. Song W, Wang K, Yang X, Dai W, Fan Z. Long noncoding RNA BANCR mediates esophageal squamous cell carcinoma progression by regulating the IGF1R/Raf/MEK/ERK pathway via miR3383p. Int J Mol Med. 2020;46(4):1377-88.

80. Luan X, Wang Y. LncRNA XLOC_006390 facilitates cervical cancer tumorigenesis and metastasis as a ceRNA against miR-331-3p and miR-338-3p. J Gynecol Oncol. 2018;29(6):e95.

81. Moghbeli M, Forghanifard MM, Sadrizadeh A, Mozaffari HM, Golmakani E, Abbaszadegan MR. Role of Msi1 and MAML1 in regulation of notch signaling pathway in patients with esophageal squamous cell carcinoma. J Gastrointest Cancer. 2015;46(4):365-9. 
82. Chen Q, Guo SM, Huang HQ, Huang GP, Li Y, Li ZH, et al. Long noncoding RNA SBF2-AS1 contributes to the growth and metastatic phenotypes of NSCLC via regulating miR-338-3p/ADAM17 axis. Aging (Albany NY). 2020;12(18):17902-20.

83. Ji D, Hu G, Zhang X, Yu T, Yang J. Long non-coding RNA DSCAM-AS1 accelerates the progression of hepatocellular carcinoma via sponging miR-338-3p. Am J Transl Res. 2019;11(7):4290-302.

84. Hu C, Jiang X. Role of NRP-1 in VEGF-VEGFR2-independent tumorigenesis. Target Oncol. 2016;11(4):501-5.

85. Li M, Ning J, Li Z, Fei Q, Zhao C, Ge Y, et al. Long noncoding RNA OIP5-AS1 promotes the progression of oral squamous cell carcinoma via regulating miR-338-3p/NRP1 axis. Biomed Pharmacother Biomed Pharmacother. 2019:118:109259.

86. Chakraborty C, Sharma AR, Patra BC, Bhattacharya M, Sharma G, Lee SS. MicroRNAs mediated regulation of MAPK signaling pathways in chronic myeloid leukemia. Oncotarget. 2016;7(27):42683-97.

87. Hosni-Ahmed A, Sims M, Jones TS, Patil R, Patil S, Abdelsamed H, et al. EDL-360: a potential novel antiglioma agent. J Cancer Sci Therapy. 2014;6(9):370-7.

88. Koga M, Matsuda M, Kawamura T, Sogo T, Shigeno A, Nishida E, et al. Foxd1 is a mediator and indicator of the cell reprogramming process. Nat Commun. 2014;5:3197.

89. Ma XL, Shang F, Ni W, Zhu J, Luo B, Zhang YQ. MicroRNA-338-5p plays a tumor suppressor role in glioma through inhibition of the MAPK-signaling pathway by binding to FOXD1. J Cancer Res Clin Oncol. 2018;144(12):2351-66.

90. Hua FF, Liu SS, Zhu LH, Wang YH, Liang X, Ma N, et al. MiRNA-338-3p regulates cervical cancer cells proliferation by targeting MACC1 through MAPK signaling pathway. Eur Rev Med Pharmacol Sci. 2017;21(23):5342-52.

91. Jia F, Zhang Z, Zhang X. MicroRNA-338-3p inhibits tumor growth and metastasis in osteosarcoma cells by targeting RUNX2/CDK4 and inhibition of MAPK pathway. J Cell Biochem. 2019;120(4):6420-30.

92. Normanno N, De Luca A, Bianco C, Strizzi L, Mancino M, Maiello MR, et al. Epidermal growth factor receptor (EGFR) signaling in cancer. Gene. 2006;366(1):2-16.

93. Han F, He J, Li F, Yang J, Wei J, Cho WC, et al. Emerging roles of MicroRNAs in EGFR-targeted therapies for lung cancer. Biomed Res Int. 2015;2015:672759.

94. Aghajanian H, Cho YK, Manderfield LJ, Herling MR, Gupta M, Ho VC, et al. Coronary vasculature patterning requires a novel endothelial ErbB2 holoreceptor. Nat Commun. 2016;7:12038.

95. Rizzolio S, Rabinowicz N, Rainero E, Lanzetti L, Serini G, Norman J, et al. Neuropilin-1-dependent regulation of EGFreceptor signaling. Cancer Res. 2012;72(22):5801-11.

96. Peng Y, Liu YM, Li LC, Wang LL, Wu XL. MicroRNA-338 inhibits growth, invasion and metastasis of gastric cancer by targeting NRP1 expression. PLoS ONE. 2014;9(4):e94422.

97. Alattar M, Omo A, Elsharawy M, Li J. Neuropilin-1 expression in squamous cell carcinoma of the oesophagus. Eur J Cardiothorac Surg. 2014;45(3):514-20.

98. Ding Z, Zhu J, Zeng Y, Du W, Zhang Y, Tang H, et al. The regulation of Neuropilin 1 expression by miR-338-3p promotes non-small cell lung cancer via changes in EGFR signaling. Mol Carcinog. 2019;58(6):1019-32.

99. Liu C, Wang Z, Wang Y, Gu W. MiR-338 suppresses the growth and metastasis of OSCC cells by targeting NRP1. Mol Cell Biochem. 2015:398(1-2):115-22.

100. Pellet-Many C, Frankel P, Evans IM, Herzog B, Junemann-Ramirez M, Zachary IC. Neuropilin-1 mediates PDGF stimulation of vascular smooth muscle cell migration and signalling via p130Cas. Biochem J. 2011;435(3):609-18.

101. Abbaszadegan MR, Riahi A, Forghanifard MM, Moghbeli M. WNT and NOTCH signaling pathways as activators for epidermal growth factor receptor in esophageal squamous cell carcinoma. Cell Mol Biol Lett. 2018;23:42.

102. Bhattacharya M, Sharma AR, Sharma G, Patra BC, Lee SS, Chakraborty C. Interaction between miRNAs and signaling cascades of Wnt pathway in chronic lymphocytic leukemia. J Cell Biochem. 2020;121(11):4654-66.

103. Moghbeli M, Abbaszadegan MR, Golmakani E, Forghanifard MM. Correlation of Wnt and NOTCH pathways in esophageal squamous cell carcinoma. J Cell Commun Signaling. 2016;10(2):129-35.

104. Torre LA, Bray F, Siegel RL, Ferlay J, Lortet-Tieulent J, Jemal A. Global cancer statistics, 2012. CA Cancer J Clin. 2015;65(2):87-108.

105. Ferlay J, Soerjomataram I, Dikshit R, Eser S, Mathers C, Rebelo M, et al. Cancer incidence and mortality worldwide: sources, methods and major patterns in GLOBOCAN 2012. Int J Cancer. 2015;136(5):E359-86.

106. Hersh CP, Silverman EK, Gascon J, Bhattacharya S, Klanderman BJ, Litonjua AA, et al. SOX5 is a candidate gene for chronic obstructive pulmonary disease susceptibility and is necessary for lung development. Am J Respir Crit Care Med. 2011;183(11):1482-9

107. Zheng JJ, Que QY, Xu HT, Luo DS, Sun Z, Ni JS, et al. Hypoxia activates SOX5/Wnt/beta-catenin signaling by suppressing MiR-338-3p in gastric cancer. Technol Cancer Res Treat. 2020;19:1533033820905825.

108. Liang W, Chen X, Zhang S, Fang J, Chen M, Xu Y, et al. Mesenchymal stem cells as a double-edged sword in tumor growth: focusing on MSC-derived cytokines. Cell Mol Biol Lett. 2021;26(1):3.

109. Xu S, Zhang H, Wang A, Ma Y, Gan Y, Li G. Silibinin suppresses epithelial-mesenchymal transition in human nonsmall cell lung cancer cells by restraining RHBDD1. Cell Mol Biol Lett. 2020;25:36.

110. Izadpanah MH, Abbaszadegan MR, Fahim Y, Forghanifard MM. Ectopic expression of TWIST1 upregulates the stemness marker OCT4 in the esophageal squamous cell carcinoma cell line KYSE30. Cell Mol Biol Lett. 2017;22:33.

111. Logan CY, Nusse R. The Wnt signaling pathway in development and disease. Annu Rev Cell Dev Biol. 2004:20:781-810.

112. Song B, Lin HX, Dong LL, Ma JJ, Jiang ZG. MicroRNA-338 inhibits proliferation, migration, and invasion of gastric cancer cells by the Wnt/beta-catenin signaling pathway. Eur Rev Med Pharmacol Sci. 2018;22(5):1290-6.

113. Tsarfaty I, Rong S, Resau JH, Rulong S, da Silva PP, Vande Woude GF. The Met proto-oncogene mesenchymal to epithelial cell conversion. Science. 1994;263(5143):98-101.

114. Zhou HY, Pon YL, Wong AS. HGF/MET signaling in ovarian cancer. Curr Mol Med. 2008;8(6):469-80.

115. Zhang R, Shi H, Ren F, Feng W, Cao Y, Li G, et al. MicroRNA-338-3p suppresses ovarian cancer cells growth and metastasis: implication of Wnt/catenin beta and MEKJERK signaling pathways. J Exp Clin Cancer Res: CR. 2019;38(1):494. 
116. Niu Q, Liu Z, Gao J, Wang Q. MiR-338-3p enhances ovarian cancer cell sensitivity to cisplatin by downregulating WNT2B. Yonsei Med J. 2019;60(12):1146-56.

117. Skoda AM, Simovic D, Karin V, Kardum V, Vranic S, Serman L. The role of the Hedgehog signaling pathway in cancer: a comprehensive review. Bosn J Basic Med Sci. 2018;18(1):8-20.

118. Cohen MM Jr. The hedgehog signaling network. Am J Med Genet A. 2003;123A(1):5-28.

119. Ruiz i Altaba A, Sanchez P, Dahmane N. Gli and hedgehog in cancer: tumours, embryos and stem cells. Nat Rev Cancer. 2002;2(5):361-72.

120. Xue Q, Sun K, Deng HJ, Lei ST, Dong JQ, Li GX. MicroRNA-338-3p inhibits colorectal carcinoma cell invasion and migration by targeting smoothened. Jpn J Clin Oncol. 2014;44(1):13-21.

121. Huang XH, Chen JS, Wang $Q$, Chen XL, Wen L, Chen LZ, et al. miR-338-3p suppresses invasion of liver cancer cell by targeting smoothened. J Pathol. 2011;225(3):463-72.

122. Martini M, De Santis MC, Braccini L, Gulluni F, Hirsch E. PI3K/AKT signaling pathway and cancer: an updated review. Ann Med. 2014;46(6):372-83.

123. Berger MF, Hodis E, Heffernan TP, Deribe YL, Lawrence MS, Protopopov A, et al. Melanoma genome sequencing reveals frequent PREX2 mutations. Nature. 2012;485(7399):502-6.

124. Guo B, Liu L, Yao J, Ma R, Chang D, Li Z, et al. miR-338-3p suppresses gastric cancer progression through a PTENAKT axis by targeting P-REX2a. Mol Cancer Res: MCR. 2014;12(3):313-21.

125. Chen X, Pan M, Han L, Lu H, Hao X, Dong Q. miR-338-3p suppresses neuroblastoma proliferation, invasion and migration through targeting PREX2a. FEBS Lett. 2013;587(22):3729-37.

126. Howitt J, Lackovic J, Low LH, Naguib A, Macintyre A, Goh CP, et al. Ndfip1 regulates nuclear Pten import in vivo to promote neuronal survival following cerebral ischemia. J Cell Biol. 2012;196(1):29-36.

127. LiY, Low LH, Putz U, Goh CP, Tan SS, Howitt J. Rab5 and Ndfip1 are involved in Pten ubiquitination and nuclear trafficking. Traffic. 2014;15(7):749-61.

128. Besse A, Sana J, Lakomy R, Kren L, Fadrus P, Smrcka M, et al. MiR-338-5p sensitizes glioblastoma cells to radiation through regulation of genes involved in DNA damage response. Tumour Biol. 2016;37(6):7719-27.

129. Linnerth-Petrik NM, Santry LA, Moorehead R, Jucker M, Wootton SK, Petrik J. Akt isoform specific effects in ovarian cancer progression. Oncotarget. 2016;7(46):74820-33.

130. Mundi PS, Sachdev J, McCourt C, Kalinsky K. AKT in cancer: new molecular insights and advances in drug development. Br J Clin Pharmacol. 2016;82(4):943-56.

131. Du K, Montminy M. CREB is a regulatory target for the protein kinase Akt/PKB. J Biol Chem. 1998;273(49):32377-9.

132. Liu J, Cao L, Zhao N, Feng Y, Yu Z, Li Y, et al. miR3383p inhibits A549 lung cancer cell proliferation and invasion by targeting AKT and betacatenin signaling pathways. Mol Med Rep. 2019;20(1):33-40.

133. Sui GQ, Fei D, Guo F, Zhen X, Luo Q, Yin S, et al. MicroRNA-338-3p inhibits thyroid cancer progression through targeting AKT3. Am J Cancer Res. 2017;7(5):1177-87.

134. Long J, Luo J, Yin X. MiR-338-5p promotes the growth and metastasis of malignant melanoma cells via targeting CD82. Biomed Pharmacother Biomed Pharmacother. 2018;102:1195-202.

135. Mizushima N, Yoshimori T, Levine B. Methods in mammalian autophagy research. Cell. 2010;140(3):313-26.

136. White E. The role for autophagy in cancer. J Clin Invest. 2015;125(1):42-6.

137. Lu R, Yang Z, Xu G, Yu S. miR-338 modulates proliferation and autophagy by PI3K/AKT/mTOR signaling pathway in cervical cancer. Biomed Pharmacother Biomed Pharmacother. 2018;105:633-44.

138. Itakura E, Kishi C, Inoue K, Mizushima N. Beclin 1 forms two distinct phosphatidylinositol 3-kinase complexes with mammalian Atg14 and UVRAG. Mol Biol Cell. 2008;19(12):5360-72.

139. Lv Q, Hua F, Hu ZW. DEDD, a novel tumor repressor, reverses epithelial-mesenchymal transition by activating selective autophagy. Autophagy. 2012;8(11):1675-6.

140. Lv Q, Wang W, Xue J, Hua F, Mu R, Lin H, et al. DEDD interacts with PI3KC3 to activate autophagy and attenuate epithelial-mesenchymal transition in human breast cancer. Cancer Res. 2012;72(13):3238-50.

141. Chu CA, Lee CT, Lee JC, Wang YW, Huang CT, Lan SH, et al. MiR-338-5p promotes metastasis of colorectal cancer by inhibition of phosphatidylinositol 3-kinase, catalytic subunit type 3-mediated autophagy pathway. EBioMedicine. 2019:43:270-81.

142. He W, Craparo A, Zhu Y, O'Neill TJ, Wang LM, Pierce JH, et al. Interaction of insulin receptor substrate-2 (IRS-2) with the insulin and insulin-like growth factor I receptors. Evidence for two distinct phosphotyrosine-dependent interaction domains within IRS-2. J Biol Chemi. 1996;271(20):11641-5.

143. White MF. IRS proteins and the common path to diabetes. Am J Physiol Endocrinol Metab. 2002;283(3):E413-22.

144. Landis J, Shaw LM. Insulin receptor substrate 2-mediated phosphatidylinositol 3-kinase signaling selectively inhibits glycogen synthase kinase 3beta to regulate aerobic glycolysis. J Biol Chem. 2014;289(26):18603-13.

145. Zhang P, Shao G, Lin X, Liu Y, Yang Z. MiR-338-3p inhibits the growth and invasion of non-small cell lung cancer cells by targeting IRS2. Am J Cancer Res. 2017;7(1):53-63.

146. Li C, Zhang K, Chen J, Chen L, Wang R, Chu X. MicroRNAs as regulators and mediators of forkhead box transcription factors function in human cancers. Oncotarget. 2017:8(7):12433-50.

147. Wang G, Sun Y, He Y, Ji C, Hu B, Sun Y. MicroRNA-338-3p inhibits cell proliferation in hepatocellular carcinoma by target forkhead box P4 (FOXP4). Int J Clin Exp Pathol. 2015;8(1):337-44.

148. Song GD, Sun Y, Shen H, Li W. SOX4 overexpression is a novel biomarker of malignant status and poor prognosis in breast cancer patients. Tumour Biol. 2015;36(6):4167-73.

149. Wang L, Zhang J, Yang X, Chang YW, Qi M, Zhou Z, et al. SOX4 is associated with poor prognosis in prostate cancer and promotes epithelial-mesenchymal transition in vitro. Prostate Cancer Prostatic Dis. 2013;16(4):301-7.

150. Rhodes DR, Yu J, Shanker K, Deshpande N, Varambally R, Ghosh D, et al. Large-scale meta-analysis of cancer microarray data identifies common transcriptional profiles of neoplastic transformation and progression. Proc Natl Acad Sci U S A. 2004;101(25):9309-14.

151. Scharer CD, McCabe CD, Ali-Seyed M, Berger MF, Bulyk ML, Moreno CS. Genome-wide promoter analysis of the SOX4 transcriptional network in prostate cancer cells. Cancer Res. 2009;69(2):709-17. 
152. Tong Z, Meng X, Wang J, Wang L. MicroRNA-338-3p targets SOX4 and inhibits cell proliferation and invasion of renal cell carcinoma. Exp Ther Med. 2017;14(5):5200-6.

153. Tiwari N, Tiwari VK, Waldmeier L, Balwierz PJ, Arnold P, Pachkov M, et al. Sox4 is a master regulator of epithelial-mesenchymal transition by controlling Ezh2 expression and epigenetic reprogramming. Cancer Cell. 2013;23(6):768-83.

154. Jin Y, Zhao M, Xie Q, Zhang H, Wang Q, Ma Q. MicroRNA-338-3p functions as tumor suppressor in breast cancer by targeting SOX4. Int J Oncol. 2015;47(4):1594-602.

155. Huang N, Wu Z, Lin L, Zhou M, Wang L, Ma H, et al. MiR-338-3p inhibits epithelial-mesenchymal transition in gastric cancer cells by targeting ZEB2 and MACC1/Met/Akt signaling. Oncotarget. 2015;6(17):15222-34.

156. Tsuchiya S, Oku M, Imanaka Y, Kunimoto R, Okuno Y, Terasawa K, et al. MicroRNA-338-3p and microRNA-451 contribute to the formation of basolateral polarity in epithelial cells. Nucleic Acids Res. 2009;37(11):3821-7.

157. Lu M, Huang H, Yang J, Li J, Zhao G, Li W, et al. miR-338-3p regulates the proliferation, apoptosis and migration of SW480 cells by targeting MACC1. Exp Ther Med. 2019;17(4):2807-14.

158. Zhang C, Li H, Wang J, Zhang J, Hou X. MicroRNA-338-3p suppresses cell proliferation, migration and invasion in human malignant melanoma by targeting MACC1. Exp Ther Med. 2019;18(2):997-1004.

159. Zou T, Duan J, Liang J, Shi H, Zhen T, Li H, et al. miR-338-3p suppresses colorectal cancer proliferation and progression by inhibiting MACC1. Int J Clin Exp Pathol. 2018;11(4):2256-67.

160. Zhang R, Shi H, Ren F, Liu Z, Ji P, Zhang W, et al. Down-regulation of miR-338-3p and up-regulation of MACC1 indicated poor prognosis of epithelial ovarian cancer patients. J Cancer. 2019;10(6):1385-92.

161. Shang C, Hong Y, Guo Y, Xue YX. Mir-338-3p inhibits malignant biological behaviors of glioma cells by targeting MACC1 gene. Med Sci Monit. 2016;22:710-6.

162. Chen Y, Li X, Wu S, Xu G, Zhou Y, Gong L, et al. Expression of HIF-1alpha and CAIX in nasopharyngeal carcinoma and their correlation with patients' prognosis. Med Oncol. 2014;31(12):304.

163. Pan WL, Wong JH, Fang EF, Chan YS, Ng TB, Cheung RC. Preferential cytotoxicity of the type I ribosome inactivating protein alpha-momorcharin on human nasopharyngeal carcinoma cells under normoxia and hypoxia. Biochem Pharmacol. 2014;89(3):329-39.

164. Fei M, Guan J, Xue T, Qin L, Tang C, Cui G, et al. Hypoxia promotes the migration and invasion of human hepatocarcinoma cells through the HIF-1alpha-IL-8-Akt axis. Cell Mol Biol Lett. 2018;23:46.

165. Feng W, Xue T, Huang S, Shi Q, Tang C, Cui G, et al. HIF-1alpha promotes the migration and invasion of hepatocellular carcinoma cells via the IL-8-NF-kappaB axis. Cell Mol Biol Lett. 2018;23:26.

166. He J, Wang J, Li S, Li T, Chen K, Zhang S. Hypoxia-inhibited miR-338-3p suppresses breast cancer progression by directly targeting ZEB2. Cancer Sci. 2020;111(10):3550-63.

167. Shan Y, Li X, You B, Shi S, Zhang Q, You Y. MicroRNA-338 inhibits migration and proliferation by targeting hypoxiainduced factor 1alpha in nasopharyngeal carcinoma. Oncol Rep. 2015;34(4):1943-52.

168. Xu H, Zhao L, Fang Q, Sun J, Zhang S, Zhan C, et al. MiR-338-3p inhibits hepatocarcinoma cells and sensitizes these cells to sorafenib by targeting hypoxia-induced factor 1alpha. PLoS ONE. 2014;9(12):e115565.

169. Chuvpilo S, Avots A, Berberich-Siebelt F, Glockner J, Fischer C, Kerstan A, et al. Multiple NF-ATc isoforms with individual transcriptional properties are synthesized in T lymphocytes. J Immunol. 1999;162(12):7294-301.

170. He W, Lu J. MiR-338 regulates NFATc1 expression and inhibits the proliferation and epithelial-mesenchymal transition of human non-small-cell lung cancer cells. Mol Genet Genomic Med. 2020;8(2):e1091.

171. Comijn J, Berx G, Vermassen P, Verschueren K, van Grunsven L, Bruyneel E, et al. The two-handed E box binding zinc finger protein SIP1 downregulates E-cadherin and induces invasion. Mol Cell. 2001;7(6):1267-78.

172. Rosivatz E, Becker I, Specht K, Fricke E, Luber B, Busch R, et al. Differential expression of the epithelial-mesenchymal transition regulators snail, SIP1, and twist in gastric cancer. Am J Pathol. 2002;161(5):1881-91.

173. Oda N, Abe M, Sato Y. ETS-1 converts endothelial cells to the angiogenic phenotype by inducing the expression of matrix metalloproteinases and integrin beta3. J Cell Physiol. 1999;178(2):121-32.

174. Zhang L, Yan R, Zhang SN, Zhang HZ, Ruan XJ, Cao Z, et al. MicroRNA-338-3p inhibits the progression of bladder cancer through regulating ETS1 expression. Eur Rev Med Pharmacol Sci. 2019;23(5):1986-95.

175. Caubit X, Lye CM, Martin E, Core N, Long DA, Vola C, et al. Teashirt 3 is necessary for ureteral smooth muscle differentiation downstream of SHH and BMP4. Development. 2008;135(19):3301-10.

176. Li Y, Huang Y, Qi Z, Sun T, Zhou Y. MiR-338-5p promotes glioma cell invasion by regulating TSHZ3 and MMP2. Cell Mol Neurobiol. 2018;38(3):669-77.

177. Komori T, Yagi H, Nomura S, Yamaguchi A, Sasaki K, Deguchi K, et al. Targeted disruption of Cbfa1 results in a complete lack of bone formation owing to maturational arrest of osteoblasts. Cell. 1997;89(5):755-64.

178. Wen C, Liu X, Ma H, Zhang W, Li H. miR3383p suppresses tumor growth of ovarian epithelial carcinoma by targeting Runx2. Int J Oncol. 2015;46(5):2277-85.

179. Nicolini A, Ferrari P, Duffy MJ. Prognostic and predictive biomarkers in breast cancer: past, present and future. Semin Cancer Biol. 2018;52(Pt 1):56-73.

180. Luo J, Zeng S, Tian C. MORC4 promotes chemoresistance of luminal A/B breast cancer via STAT3-mediated MID2 upregulation. Onco Targets Ther. 2020;13:6795-803.

181. Duan X, Guo G, Pei X, Wang X, Li L, Xiong Y, et al. Baicalin inhibits cell viability, migration and invasion in breast cancer by regulating miR-338-3p and MORC4. Onco Targets Ther. 2019;12:11183-93.

182. Moghbeli M, Moaven O, Memar B, Raziei HR, Aarabi A, Dadkhah E, et al. Role of hMLH1 and E-cadherin promoter methylation in gastric cancer progression. J Gastrointest Cancer. 2014;45(1):40-7.

183. Nan X, Campoy FJ, Bird A. MeCP2 is a transcriptional repressor with abundant binding sites in genomic chromatin. Cell. 1997:88(4):471-81.

184. Tong D, Zhao L, He K, Sun H, Cai D, Ni L, et al. MECP2 promotes the growth of gastric cancer cells by suppressing miR-338-mediated antiproliferative effect. Oncotarget. 2016;7(23):34845-59.

185. Li P, Chen X, Su L, Li C, Zhi Q, Yu B, et al. Epigenetic silencing of miR-338-3p contributes to tumorigenicity in gastric cancer by targeting SSX2IP. PLOS ONE. 2013;8(6):e66782. 
186. Timpl R, Sasaki T, Kostka G, Chu ML. Fibulins: a versatile family of extracellular matrix proteins. Nat Rev Mol Cell Biol. 2003;4(6):479-89.

187. Rahn DD, Acevedo JF, Roshanravan S, Keller PW, Davis EC, Marmorstein LY, et al. Failure of pelvic organ support in mice deficient in fibulin-3. Am J Pathol. 2009;174(1):206-15.

188. Wen PY, Kesari S. Malignant gliomas in adults. N Engl J Med. 2008;359(5):492-507.

189. Albig AR, Neil JR, Schiemann WP. Fibulins 3 and 5 antagonize tumor angiogenesis in vivo. Cancer Res. 2006;66(5):2621-9.

190. Hu Y, Pioli PD, Siegel E, Zhang Q, Nelson J, Chaturbedi A, et al. EFEMP1 suppresses malignant glioma growth and exerts its action within the tumor extracellular compartment. Mol Cancer. 2011;10:123.

191. Lei D, Zhang F, Yao D, Xiong N, Jiang X, Zhao H. MiR-338-5p suppresses proliferation, migration, invasion, and promote apoptosis of glioblastoma cells by directly targeting EFEMP1. Biomed Pharmacother Biomed Pharmacother. 2017;89:957-65.

192. Nurden AT, Fiore M, Nurden P, Pillois X. Glanzmann thrombasthenia: a review of ITGA2B and ITGB3 defects with emphasis on variants, phenotypic variability, and mouse models. Blood. 2011;118(23):5996-6005.

193. leguchi K, Fujita M, Ma Z, Davari P, Taniguchi Y, Sekiguchi K, et al. Direct binding of the EGF-like domain of neuregulin-1 to integrins (\{alpha\}v\{beta\}3 and \{alpha\}6\{beta\}4) is involved in neuregulin-1/ErbB signaling. J Biol Chem. 2010;285(41):31388-98.

194. Mori S, Wu CY, Yamaji S, Saegusa J, Shi B, Ma Z, et al. Direct binding of integrin alphavbeta3 to FGF1 plays a role in FGF1 signaling. J Biol Chem. 2008;283(26):18066-75.

195. Saegusa J, Yamaji S, leguchi K, Wu CY, Lam KS, Liu FT, et al. The direct binding of insulin-like growth factor-1 (IGF-1) to integrin alphavbeta3 is involved in IGF-1 signaling. J Biol Chem. 2009;284(36):24106-14.

196. Vellon L, Menendez JA, Lupu R. AlphaVbeta3 integrin regulates heregulin (HRG)-induced cell proliferation and survival in breast cancer. Oncogene. 2005;24(23):3759-73.

197. Chen X, Wei L, Zhao S. miR-338 inhibits the metastasis of lung cancer by targeting integrin beta3. Oncol Rep. 2016;36(3):1467-74

198. Mittal K, Choi DH, Klimov S, Pawar S, Kaur R, Mitra AK, et al. A centrosome clustering protein, KIFC1, predicts aggressive disease course in serous ovarian adenocarcinomas. J Ovarian Res. 2016;9:17.

199. Xiao YX, Yang WX. KIFC1: a promising chemotherapy target for cancer treatment? Oncotarget. 2016;7(30):48656-70.

200. Li G, Chong T, Yang J, Li H, Chen H. Kinesin motor protein KIFC1 is a target protein of miR-338-3p and is associated with poor prognosis and progression of renal cell carcinoma. Oncol Res. 2018;27(1):125-37.

201. Lotz GP, Lin H, Harst A, Obermann WM. Aha1 binds to the middle domain of Hsp90, contributes to client protein activation, and stimulates the ATPase activity of the molecular chaperone. J Biol Chem. 2003;278(19):17228-35.

202. Cao R, Shao J, Hu Y, Wang L, Li Z, Sun G, et al. microRNA-338-3p inhibits proliferation, migration, invasion, and EMT in osteosarcoma cells by targeting activator of $90 \mathrm{kDa}$ heat shock protein ATPase homolog 1. Cancer Cell Int. 2018:18:49.

203. Sun J, Feng X, Gao S, Xiao Z. microRNA-338-3p functions as a tumor suppressor in human nonsmallcell lung carcinoma and targets Ras-related protein 14. Mol Med Rep. 2015;11(2):1400-6.

204. Shida D, Takabe K, Kapitonov D, Milstien S, Spiegel S. Targeting SphK1 as a new strategy against cancer. Curr Drug Targets. 2008;9(8):662-73.

205. Venkata JK, An N, Stuart R, Costa LJ, Cai H, Coker W, et al. Inhibition of sphingosine kinase 2 downregulates the expression of c-Myc and Mcl-1 and induces apoptosis in multiple myeloma. Blood. 2014;124(12):1915-25.

206. Hait NC, Allegood J, Maceyka M, Strub GM, Harikumar KB, Singh SK, et al. Regulation of histone acetylation in the nucleus by sphingosine-1-phosphate. Science. 2009;325(5945):1254-7.

207. Xiao G, Wang Q, Li B, Wu X, Liao H, Ren Y, et al. MicroRNA-338-3p suppresses proliferation of human liver cancer cells by targeting SphK2. Oncol Res. 2018;26(8):1183-9.

208. Sun K, Su G, Deng H, Dong J, Lei S, Li G. Relationship between miRNA-338-3p expression and progression and prognosis of human colorectal carcinoma. Chin Med J. 2014;127(10):1884-90.

209. Zhang G, Zheng H, Zhang G, Cheng R, Lu C, Guo Y, et al. MicroRNA-338-3p suppresses cell proliferation and induces apoptosis of non-small-cell lung cancer by targeting sphingosine kinase 2. Cancer Cell Int. 2017;17:46

210. Demaria M, Poli V. PKM2, STAT3 and HIF-1alpha: The Warburg's vicious circle. JAKSTAT. 2012;1 (3):194-6.

211. Spoden GA, Rostek U, Lechner S, Mitterberger M, Mazurek S, Zwerschke W. Pyruvate kinase isoenzyme M2 is a glycolytic sensor differentially regulating cell proliferation, cell size and apoptotic cell death dependent on glucose supply. Exp Cell Res. 2009;315(16):2765-74.

212. Shi HS, Li D, Zhang J, Wang YS, Yang L, Zhang HL, et al. Silencing of pkm 2 increases the efficacy of docetaxel in human lung cancer xenografts in mice. Cancer Sci. 2010;101(6):1447-53.

213. Sun Q, Chen X, Ma J, Peng H, Wang F, Zha X, et al. Mammalian target of rapamycin up-regulation of pyruvate kinase isoenzyme type M2 is critical for aerobic glycolysis and tumor growth. Proc Natl Acad Sci U S A. 2011;108(10):4129-34.

214. Yang L, Xie M, Yang M, Yu Y, Zhu S, Hou W, et al. PKM2 regulates the Warburg effect and promotes HMGB1 release in sepsis. Nat Commun. 2014:5:4436.

215. Yang W, Xia Y, Hawke D, Li X, Liang J, Xing D, et al. PKM2 phosphorylates histone $\mathrm{H} 3$ and promotes gene transcription and tumorigenesis. Cell. 2012;150(4):685-96.

216. Han B, Meng X, Chen H, Chen L, Liu X, Wang H, et al. Epigenetic silencing of miR-338 facilitates glioblastoma progression by de-repressing the pyruvate kinase M2-beta-catenin axis. Aging (Albany NY). 2017;9(8):1885-97.

217. Zhang Y, Shi B, Chen J, Hu L, Zhao C. MiR-338-3p targets pyruvate kinase M2 and affects cell proliferation and metabolism of ovarian cancer. Am J Transl Res. 2016;8(7):3266-73.

218. Combs AP. Recent advances in the discovery of competitive protein tyrosine phosphatase $1 \mathrm{~B}$ inhibitors for the treatment of diabetes, obesity, and cancer. J Med Chem. 2010;53(6):2333-44. 
219. Aschrafi A, Schwechter AD, Mameza MG, Natera-Naranjo O, Gioio AE, Kaplan BB. MicroRNA-338 regulates local cytochrome c oxidase IV mRNA levels and oxidative phosphorylation in the axons of sympathetic neurons. J Neurosci. 2008;28(47):12581-90

220. Sun F, Yu M, Yu J, Liu Z, Zhou X, Liu Y, et al. miR-338-3p functions as a tumor suppressor in gastric cancer by targeting PTP1B. Cell Death Dis. 2018;9(5):522.

221. Bartoszewski R, Sikorski AF. Editorial focus: entering into the non-coding RNA era. Cell Mol Biol Lett. 2018;23:45.

\section{Publisher's Note}

Springer Nature remains neutral with regard to jurisdictional claims in published maps and institutional affiliations.

- fast, convenient online submission

- thorough peer review by experienced researchers in your field

- rapid publication on acceptance

- support for research data, including large and complex data types

- gold Open Access which fosters wider collaboration and increased citations

- maximum visibility for your research: over 100M website views per year

At BMC, research is always in progress.

Learn more biomedcentral.com/submissions 